1977

\title{
Experimental Gingivitis in the Albino Hamster
}

John Anthony Ranieri

Loyola University Chicago

Follow this and additional works at: https://ecommons.luc.edu/luc_theses

Part of the Oral Biology and Oral Pathology Commons

\section{Recommended Citation}

Ranieri, John Anthony, "Experimental Gingivitis in the Albino Hamster" (1977). Master's Theses. 2904.

https://ecommons.luc.edu/luc_theses/2904

This Thesis is brought to you for free and open access by the Theses and Dissertations at Loyola eCommons. It has been accepted for inclusion in Master's Theses by an authorized administrator of Loyola eCommons. For more information, please contact ecommons@luc.edu. (c) (i) $\Theta \Theta$

This work is licensed under a Creative Commons Attribution-Noncommercial-No Derivative Works 3.0 License. Copyright @ 1977 John Anthony Ranieri 


\section{EXPERIMENTAL GINGIVITIS}

IN THE ALBINO HAMSTER

\section{by}

John Anthony Ranieri

A Thesis Submitted to the Faculty of the Graduate School of Loyola University of Chicago in Partial Fulfillment of the Requirements for the Degree of Master of Science June 1977 


\section{DEDICATION}

To my parents, Louis and Diana Ranieri, whose encouragement, understanding, and many sacrịfices enabled me to get here. 


\section{ACKNOWLEDGMENTS}

I wish to express my deepest appreciation to $\mathrm{Dr}$. Patrick D. Toto, whose guidance and support made this thesis possible.

To Dr. Paul Goaz, for his helpful suggestions in the writing of this thesis. 


\section{VITA}

John Anthony Ranieri was born on September 30, 1953, in Chicago, Illinois.

He graduated from Holy Cross High School in June of 1971 and enrolled at Loyola University of Chicago where he graduated with a Bachelor of Science degree in Biology in June of 1975 .

He was commissioned a second Lieutenant in the U.S. Army in June of 1975, and is currently an officer in the Army Reserve.

He enrolled in the Graduate Program in Oral Biology at Loyola University School of Dentistry in September of 1975. 
DEDICATION - . . . . . . . . . . . . . . . . . ii ACKNOWLEDGMENTS . . . . . . . . . . . . . . .

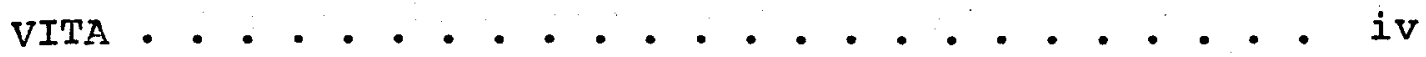

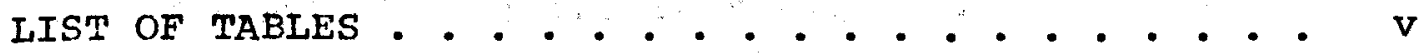
IIST OF FIGURES • . . . . . . . . . . . . . . . . vi vi CHAPTER

I. INTRODUCTION •. . . . . . . . . . . 1

II. REVIEW OF THE IITERATURE . . . . . . . . . . 3

III. MATERIALS AND METHODS. . . . . . . . . . 35

IV. RESULTS . . . . . . . . . . . . 42

V. DISCUSSION •. . . . . . . . . . . 57

VI. SUMMARY AND CONCLUSIONS . . . . . . . . . 67 BIBLIOGRAPHY . • • . . . . . . . . . . . 69 
I. Studies of Periodontal Disease Using Rodents as the Model . . . . . . . . 6-7

II. Mean Percentages of Cultivable organisms in Adult Human Oral Cavity . . . . .

III. Composition of the Test Diet . . . . . . 36

IV. Fluorescence of A. naeslundii

Reacted with Serum from Experimental and Control Hamsters

V. Agglutination of A. naeslundii with Serum from Control and Experimental Animals . . . . . . . . . . . . . . . 
1. Thin smear of Actinomyces naeslundii

in experimental serum showing positive

fluorescence... . . . . . . . . 44

2. Dense smear of $A$. naeslundii in experi-

mental serum showing positive fluores-

cence . . . . . . . . . . . . . 444

3. A. naeslundil in control serum showing

negative fluorescence . . . . . . . . . 45

4. Bacterial plaque in experimental hamsters ................ 49

5. Early gingivitis in the hamster ...... . 50

6. Early gingivitis in the hamster showing interdental papilla . . . . . . 51

7. High magnification of Figure 6. . . . . . 52

8. Interdental papilla in an experimental

hamster showing gingivitis . . . . . . . 53

9. Interdental papilla from a control hamster .. . . . . . . . . . . . 54

10. High magnification of Figure 9 .. . . . . 55

11. Low magnification of Figure 9 . . . . . 56 


\section{INTRODUCTION}

Chronic gingivitis is an inflammatory disorder of the gingiva. Past investigations have demonstrated that microbial plaque lying adjacent to the host's gingival tissues is the primary etiologic factor, initiating gingival inflammation and the ensuing periodontal disease (Löe, Theilade, and Jensen, 1965).

The bacteria and their products cause gingivitis by stimulating a reaction in the host's immune system. The humoral immune response in the host produces specific antibody as a result of the invasion by bacterial products acting as antigens (Nisengard and Beutner, 1970a, Gilmour and Nisengard, 1973l.

Numerous studies have been conducted implicating Actinomyces naeslundii as a primary etiologic agent in gingivitis and periodontitis (Socransky, Hubersak, and Propas, 1970, Marttala, Toto, and Gargiulo, 1974). The antigenic activity of cell portions of A. naeslundii has been demonstrated (Irving, Heeley, and Socransky, 1975).

In addition, specific antibody activity against Actinomyces naeslundii, A. israelii, A. viscosus, and 
Streptococcus mutans has been demonstrated in the gingiva of patients with chronic periodontal disease by use of the fluorescent antibody technique (Marttala, Toto, and Gargiulo, 1974 ).

The purpose of this investigation is to demonstrate an induction of specific antibody activity against $\underline{A}$. naeslundii in albino hamsters resulting from an oral exposure to this microorganism experimentally. The role of A. naeslundii in the initiation of experimental gingivitis in these animals will also be investigated. 


\section{CHAPTER II}

\section{REVIEW OF THE LITERATURE}

Periodontal disease has been defined as the morbid response of the periodontal tissues to extrinsic local irritants. This disease has afflicted man probably since the beginning of time and is one of the two major oral diseases. Periodontal disease is a major health problem and is said to be the most common cause of tooth loss, affecting millions in the United States alone. Furthermore, periodontal disease may become an even greater threat in the future, since longevity is increasing (Rizzo, 1973).

Much of the research concerned with periodontal disease has depended on the use of experimental animals.

For over twenty years rodents have been used as models for periodontal research. The early observations of Jordan and Keyes (1964) described a condition in hamsters characterized by gingival accumulation of plaque-like material around the molar teeth. Resultant soft tissue disturbances and alveolar bone loss indicated the potential of the hamster for studies on periodontal disease. Dental plaques have been defined as ". . dense, non-calcified 
bacterial masses so firmly adherent to the tooth surface that they resist wash off by salivary flow." (Gibbons and van Haute, 1973).

Primary consideration in the choice of an animal model nust be given to the complexity of the etiological forces involved in the disease under investigation. A simple model may be adequate where the etiological effect is potent or easily manipulated. If, however, the etiological effect is dependent upon a multiplicity of conditions, as in periodontal disease, the results might vary with different animal species. In order to study all the aspects of the disease, various species may be needed for each (Frenkel, 1969).

The way in which the model differs from the original is governed by fidelity and discrimination. Fidelity refers to the overall differences between the model and the original while discrimination describes the ability of the model to reproduce a particular property of the original. There may be drawbacks to using a model of high fidelity: this makes it impossible to simplify a complex disease situation to the stage at which elements of importance can be recognized and evaluated. Further, high fidelity alone may not justify the added difficulties presented. The rationale of using a higher animal to investigate human 
disease concepts should be related to some particular feature that is absent or unsuitable for some reason in the lower animal. Frenkel (1969) has stated that, to be meaningful, the process under investigation must be analogous to that occurring in man.

The choice of a model for periodontal disease research depends also upon the questions posed. This research deals with the role of Actinomyces naeslundii in the etiology of gingivitis in the albino hamster. In view of the fact that this is a restricted phase of the disease, the model chosen should show good discrimination for this phase. Over the years periodontal researchers have used various species of experimental animals. These include the Beagle dog (Saxe, Greene, Bohannon, and Vermillion, 1967), the Syrian hamster (Keyes and Fitzgerald, 1970), the monkey (Krygier, Genco, Mashino, and Hausmann, 1973), and the Mongolial gerbil (Moskow, Wasserman, and Rennert, 1968L, among others. The most widely used model ha's been the rodent (See Table I).

The utility of rodents has been demonstrated by their widespread use in periodontal disease research. Rodents have advantages in small size, relatively low cost of upkeep, and ease in handling, breeding, and housing (Jordan, 1971). The rodent is a predictable model in the sense of 
Studies of Periodontal Disease Using Rodents as the Model

\section{INVESTIGATOR EXPERI- MENTAL ANIMAL}

Mitchell\& Chernausek 1951

\section{Gupta, Auskaps, \& Shaw 1957 1968 \\ Jordan \& Keyes 1964}

Syrian

hamster

Albino hamster

Syrian hamster

\section{TEST ORGANISM}

None introduced

Rice rat None introduced

streptococci......

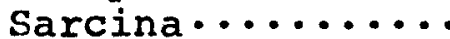
G- rods.......... G+ aerobic, filamentous bacteria

Plaque organisms
DIET USED

IF ANY DISEASE

Finely ground, high carbohydrate, with ammoniated products............. Periodontal disease Without ammon.

products..

"a reduced am't of perio.involvement"

\section{\#700 (Shaw, 1947) \\ Perio. disease \#700 with antibiotics.... Major reduction in perio. dis.}

\#2000，568 sucrose...... None observed $\# 2000,568$ sucrose....... None observed $\$ 2000,568$ sucrose...... None observed \#2000，568 sucrose....... Perio. disease includ. bone resorption from perio. diseaseprone golden \& cream hamsters 
TABIE I (cont.)

\begin{tabular}{|c|c|c|c|c|}
\hline INVESTIGATOR & $\frac{\frac{\text { EXPERI - }}{\text { MENTAI }}}{\text { ANIMAL }}$ & TEST ORGANISM & DIET USED & IF ANY DISEASE \\
\hline $\begin{array}{l}\text { Dick \& } \\
\text { Shaw, } 1966\end{array}$ & Rice rat & $\begin{array}{l}\text { Organisms in feces } \\
\text { of rice rats with } \\
\text { fully developed } \\
\text { period. lesions }\end{array}$ & \#700 (Shaw, 1947) & Periodontal disease \\
\hline $\begin{array}{l}\text { Socransky, } \\
\text { Hubersak, } \\
\& \text { Propas, } \\
1970\end{array}$ & $\begin{array}{l}\text { Sprague- } \\
\text { Dawley } \\
\text { rats }\end{array}$ & $\frac{\text { Actinomyces }}{\text { naeslundii }}$ & $\begin{array}{l}\text { \#2000 (Keyes \& } \\
\text { Jordan, 1964) }\end{array}$ & $\begin{array}{l}\text { Periodontal disease, } \\
\text { alveolar bone destruc- } \\
\text { tion, subgin. plaque } \\
\text { formation, hair impact- } \\
\text { ation, root caries }\end{array}$ \\
\hline $\begin{array}{l}\text { Jordan, } \\
\text { Keyes, \& } \\
\text { Bellack } \\
\text { 19: }\end{array}$ & $\begin{array}{l}\text { Albino } \\
\text { hamster \& } \\
\text { gnotobiotic } \\
\text { rats }\end{array}$ & $\begin{array}{l}\text { Actinomyces of } \\
\text { human origin }\end{array}$ & $\# 2000$ & $\begin{array}{l}\text { Gingival distortion, } \\
\text { pocketing, alveolo- } \\
\text { clasia, root caries }\end{array}$ \\
\hline $\begin{array}{l}\text { Miller \& } \\
\text { Ripley } \\
1975\end{array}$ & $\begin{array}{l}\text { Syrian } \\
\text { hamster }\end{array}$ & $\frac{\text { Actinomyces }}{\text { viscosus }}$ & $\begin{array}{l}\text { \#2000 (Keyes \& } \\
\text { Jordan, 1964). }\end{array}$ & $\begin{array}{l}\text { Inflammation, plaque } \\
\text { formation, bone } \\
\text { resorption }\end{array}$ \\
\hline
\end{tabular}


reproducing the disease with a high degree of reliability (Keyes, 1964, Dick and Shaw, 1966).

Dietary studies which have been performed on rodents are in agreement with observations in human populations (Jordan, Keyes, and Lim, 1969). Starch containing diets support the infection of Actinomyces viscosus in animals (Keyes and Jordan, 1964). It has been found that, in human populations, those that consume starch as the principle carbohydrate and take in little refined sugar are likely to develop periodontal disease rather than caries (Jordan, 1971).

Observations have shown that the gingival plaque found in rodents is similar to that which invests the cervical regions of the teeth in humans and it has been demonstrated that both contain species of Actinomyces (Jordan and Keyes, 1964, Slack, Lanfried, and Gerencser, 1971). Cervicoradicular infections have been induced in rodents by the use of isolates of Actinomycete-like bacteria from human plaque (Jordan and Keyes, 1964).

The implantation of Odontomyces viscosus in albino hamsters is supported by sucrose or starch diets. Glucose and fructose also support 0 . viscosus implantation in golden hamsters (Jordan, Keyes, and Lim, 1969). 
The use of germfree (gnotobiotic) rodents has proven extremely useful in testing the pathogenic properties of specific bacterial species. This has been done by observing any pathological changes which may occur in these animals subsequent to monoinfection with a particular bacterial specie (s) (Socransky, Hubersak, and Propas, 1970, Jordan, Keyes, and Bellack, 19721 .

The initiating role of bacteria in inflammatory gingival disease has been studied at length, especially over the last decade (Löe, Theilade, and Jensen, 1965, Socransky, Hubersak, and Propas, 1970, Jordan, Keyes, and Bellack, 1972, among others).

Rovin, Costich, and Gordan (1966), in their work with germfree rats, demonstrated periodontal inflammation could not occur in the absence of microorganisms. They observed both local irritation and bacteria were necessary to produce periodontal inflammation in their model.

Bacteria or their products may directly damage periodontal tissues, however, it is likely that the inflammatory process of periodontal disease is a result of the interaction between bacterial products and the host's immune system (Bahn, 1970).

In the oral cavity, a delicate balance exists between the defense mechanisms of the host and the constant 
challenge posed by the oral flora and its products. An upset in this balance may be caused by factors such as physical irritants including calculus, as well as trauma and systemic disease. Such an upset may lead to the inflammatory process of periodontal disease (Bahn, 1970).

The immune system, composed of humoral and cellular mechanisms, has as a primary function the protection of the host against microbial invasion. When antibodies (humoral) or lymphocytes (cellular) react with specific antigens, these reactions may trigger localized immediate and delayed hypersensitivities respectively, resulting in inflammation. A local inflammatory response may serve as the main defense against microbial invasion. If it persists, however, it may cause destruction of periodontal tissues (Snyderman, 1973). The type of immunologic response induced is a result of the host's initial contact with the antigen (Baram and Arnold, 1970).

Agents which include antigen-antibody complexes, bacterial endotoxin, and some proteases are capable of activating the complement sequence. As a result, several aspects of the inflammatory process, vasodilation, vascular permeability, smooth muscle constriction, and chemotaxis for leukocytes, are mediated by biologically active peptides released by the complement components $\mathrm{C} 3 \mathrm{a}$ and $\mathrm{C5a}$, 
which are anaphylatoxins (Snyderman, Phillips, and Mergenhagen, 1971). These mediators include histamine, serotonin, and bradykinin.

Jensen, Snyderman, and Mergenhagen (1969) found that C5a injected intradermally in guinea pigs resulted in localized enhanced vascular permeability, vasodilation, and a massive buildup of polymorphonuçlear leukocytes. Further, the ability of C5a to contract smooth muscle in vitro has been demonstrated (Jensen, 1967).

As a consequence of an induction of inflammation by pharmacologically active mediators, there is increased exudate from regional capillaries into tissues causing edema and increased penetration of bacterial antigens. Bacteria may continue to stimulate antibody formation locally in regional lymph nodes and in adjacent tissues (Mergenhagen, 1967).

The main source of histamine in the connective tissues is the mast cells (Seyle, 1965). Complement has been implicated in the formation of a factor that releases this histamine from the mast cells (Hook, snyderman, and Mergenhagen, 1970). Several biological properties of heparin, also released from mast cells, are related to the inflammatory process, but these are less significant than its ability to enhance bone resorption in vitro (Goldhaber, 1965). 
The gingiva has been revealed to be a potential reservoir of histamine, the major portion of which is stored in the mast cells (Schwartz and Dibblee, 1975b). When appropriately challenged in vitro, the gingiva can release this histamine. The authors reported a significant release of gingival histamine subsequent to challenge by each of the enzymes protease, collagenase, trypsin, and chymotrypsin. This histamine release may contribute to chronic periodontal inflammation.

IgE immunoglobulins are cytotropic and are known to have a strong affinity for the surface receptors of mast cells of homologous species (Papermaster, 1972). These findings have been supported by the recent investigation of Schwartz and Dibblee (1975a) who demonstrated a close association of IgE with gingival mast cell histamine release in vitro.

Bacterial antigens may be categorized into three main types. These are: 1. the peptidoglycans, 2. lipopolysaccharide endotoxins, and 3. proteins such as enzymes, structural proteins, and protein complexes containing polysaccharide and lipid, which are produced by oral microorganisms (Bahn, 1970). These may be allergens, causing an allergic or hypersensitive response in some predisposed individuals. Chronic inflammation may result from the 
continued presence of these allergens in plaque (Bahn, 1970). Peptidoglycans comprise the muco-peptide layex of the cell wall of gram positive bacteria. Peptidoglycan is immunogenic and, combined with complement present in gingival fluid, may initiate an inflammatory response (Bahn, 1970). Penetration of the gingival epithelium and subsequent interaction with local antibodies by the gingival sulcus bacteria Streptococcus mitis, streptococcus salivarius, and Neisseria catarrhalis has been demonstrated (Mayron, 1973). Polymorphonuclear leukocytes (PMN's) are phagocytic cells which may contribute to tissue destruction by releasing intracellular products from their lysosomes during phagocytosis (Cohn and Hirsch, 1960, Cochrane, 1969). Indeed, a widening of the intracellular spaces in human gingival sulcus epithelium subsequent to the application of intracellular enzymes from human PMN's has been observed (Thilander, 1963). Further, it has been demonstrated that the early inflammatory response to intradermal injections of mixed cultures of oral bacteria (Jensen and Mergenhagen, 1964) and to intradermal injection of dental plaque containing viable bacteria (Taichman, Friedman, and Uriukara, 1966) is greatly reduced in rabbits previously rendered leukopenic. Significantly, a prevention of tissue damage due to the inflammatory response in the Arthus and local Schwartzman 
reactions has been observed in leukopenic rabbits (Stetson, 1951). In addition to these effects, it has been demonstrated that lysosomal enzymes derived from inflammatory cells are capable of stimulating bone decalcification in vitro (Fell, Coombs, and Dingle, 1966).

It has been found that the number of PMN's in the gingival sulcus during the course of experimental gingivitis in man is increased (Löe, Theilade, and Jensen, 1965). Further, it has been postulated that the number of PMN's present may reflect the degree of inflammation in the gingival tissues (Klinkhamer, 1968).

Experimentally, in vitro and in vivo, it has been demonstrated that PMN's respond to chemotactic factors (Harris, 1954, Keller and Sorkin, 1967).

Tempel, Snyderman, Jordan, and Mergenhagen (1970) classified agents causing chemotaxis for PMN's into two categories: agents which exert their influence on PMN's directly, such as bacterial chemotactic factors, and those agents which are chemotactic by virtue of an interaction with host factors. The authors, in their investigation of factors chemotactic for PMN's, found that all strains of oral bacteria evaluated produced chemotaxis for PMN's. That viable bacteria produce a product directly chemotactic for neutrophils in vitro had previously been documented 
(Keller and Sorkin, 1967, Ward, Lepow, and Newman, 1968, Walker, Barlet, and Kurtz, 1969). This work was supported by snyderman (1973) who observed filtrates from cultures of three strains of bacteria isolated from human dental plaque to be distinctly chemotactic for PMN's. The recent investigation of Miller, Folke, and Umana (1975) demonstrated dental plaque to be consistently chemotactic in vitro for human PMN's. Plaque supernatant was found to be approximately sixty percent less chemotactic than whole plaque, implicating the bacteria as primary chemotactic factors. This contention was substantiated by the demonstration of negligible chemotactic activity in the ultrafiltrate, which contained no bacteria. The authors found antigen-antibody complexes, used as positive controls, were more chemotactic than whole plaque suspensions. This finding supported the work of Boyden (1962) who had previously demonstrated the chemotactic activity of ag-ab complexes.

In addition to the humoral mechanism of the immune system and its role in the etiology of periodontal disease, the cellular response has been studied at length (Burnett and Scherp, 1968, Bahn, 1970, Irving, Heeley, and Socransky, 1975, among others). An analysis of the cellular response in periodontal patients has shown that these patients have 
lymphocytes which are more reactive than those found in normal individuals (Horton, Leikin, and Oppenheim, 1972). Further, it has been demonstrated that lymphocytes from individuals with cellular immune hypersensitivity undergo a proliferative response (Iymphocyte transformation) when cultured in vitro with a specific antigen (Oppenheim, 1969). Significantly, it has been observed that lymphocytes release soluble mediators of inflammation before and during transformation (Pick and Turk, 1972). Included among these lymphocyte-derived mediators are a monocyte chemotactic factor (LDCF), a cytotoxic factor (Lymphotoxin), and a macrophage inhibitory factor (MIF). These mediators are called lymphokines (Snyderman, 1973).

Pertinent at this point in the discussion is the observation that lymphocytes obtained from patients with destructive periodontal disease (as evidenced by a high Periodontal Index or PDI) are distinctly cytotoxic for gingival epithelial cells in vitro. At the same time, no significant Iymphocytotoxicity was demonstrated on the part of aggressor lymphocytes from periodontal disease-free (low PDI) patients (Movius, Rogers III, and Reeve, 1975).

Other factors reportedly released by stimulated lymphocytes include mitogenic factors (Dumonde, Howson, and Wolstencroft, 1967) and a factor that inhibits cellular 
proliferation (Green, Cooperband, Rutstein, and Kibrick, 1970), the latter effect possibly preventing tissue repair. studies have demonstrated substances in plaque, derived from oral bacteria, are capable of initiating a cellular immune response. Ivanyi and Lehner (1970) were successful in isolating a lymphoproliferative initiator material from four strains of bacteria commonly found in the human oral cavity. It has been found that lymphocytes from patients having periodontal disease undergo a proliferative response when exposed to plaque antigens. Further, the degree of lymphocyte transformation is directly related to the severity of the lymphocyte donor's periodontal disease (Horton, Leikin, and Oppenheim, 1972).

As a result of the interaction of plaque with leukocytes cultured from periodontal patients, a release of lymphotoxin has been observed (Horton, Oppenheim, and Mergenhagen, 1973). In addition, the authors found that the amount of lymphotoxin produced was directly proportional to the severity of the leukocyte donor's periodontal disease. The lymphotoxin was cytotoxic for human fibroblast cultures in vitro.

Supernatant fluids of human leukocyte cultures stimulated by dental extracts have been found to contain, in addition to lymphotoxin, a substance which has produced 
bone resorption in organ cultures of fetal rat bone. This effect may have been a consequence of an observed increase in the number of active osteoclasts in the bone cultures, apparently caused by this substance. As an osteoclast activating factor (OAFl, this lymphokine may be the cause of the alveolar bone loss seen in advanced periodontal disease (Horton, Raisz, Simmons, Oppenheim, and Mergenhagen, 1972). The presence of microorganisms in the gingival crevice has been known since their description by Leeuwenhoek in 1678 (Arnim, 1967). A review of the literature reveals that periodontal inflammation does not occur in the absence of microorganisms. For example; in an investigation of periodontal disease in rats; Rovin, Costich, and Gordon (1966) observed that, in germfree rats, local irritation in the form of silk ligatures placed at the cervical margins of the first molars was not sufficient to cause periodontal inflammation. Inflammation occurred only in the presence of microorganisms found in conventional rats.

The observation has been made that periodontal disease is infectious in origin and has not been known to occur in the absence of an infectious agent (Ellison, 1970). A table of the normal human oral flora is found in Table II. The accumulation of bacterial plaque in man has been directly correlated with increased inflammation of gingival 
Mean Percentages of Cultivable Organisms in Adult Huma Oral Cavity (Socransky and Manganiello, 1971)

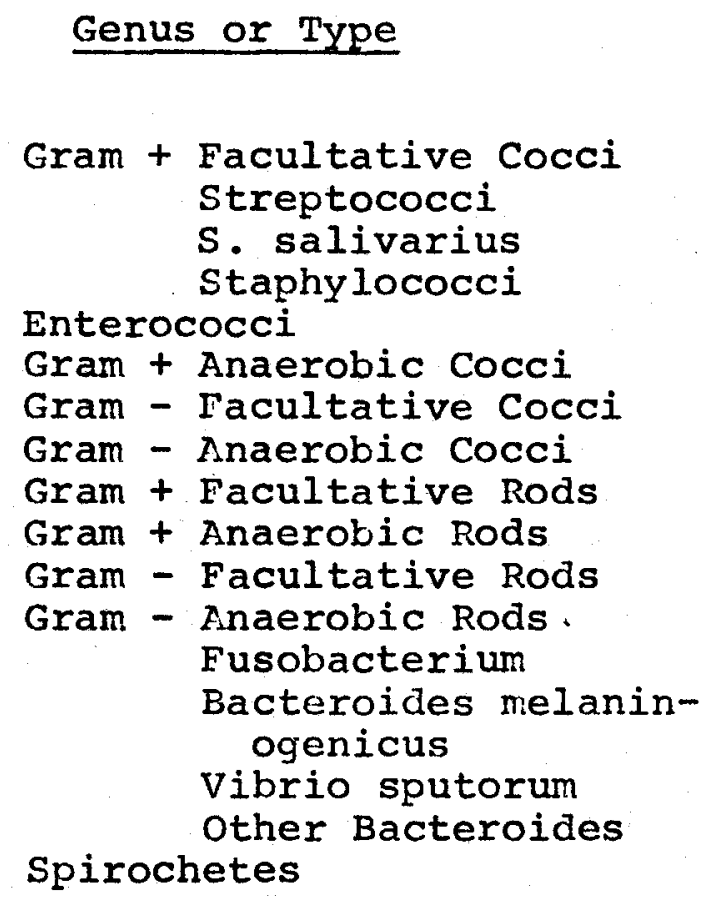

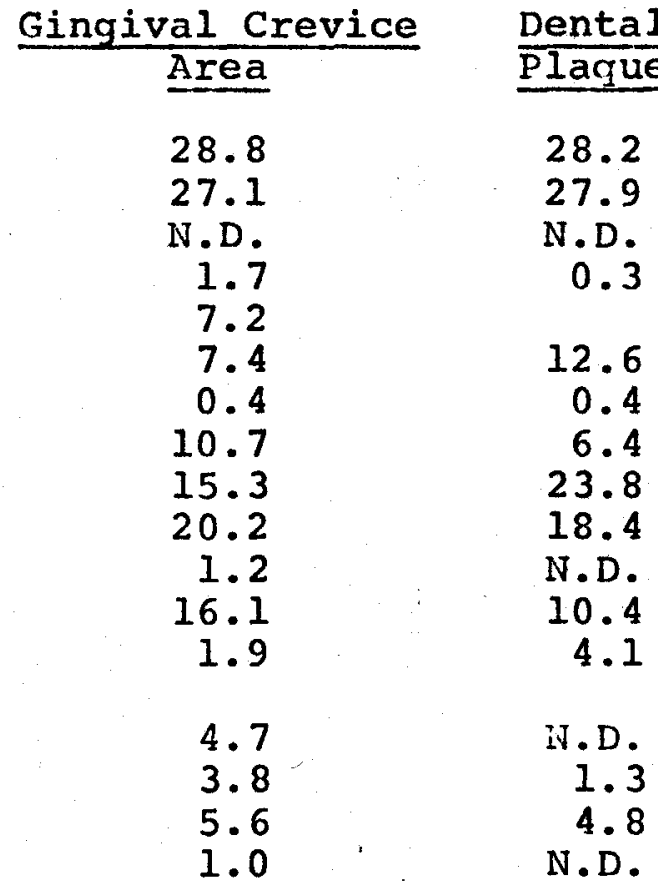

Tongue

Saliva

44.8

38.3

8.2

6.5

N.D.

4.2

3.4

16.0

13.0

8.2

3.2

8.2

0.7

0.2

2.2

5.1

N.D.
46.2

41.0

4.6

4.0

1.3

13.0

1.2

15.9

11.8

4.8

2.3

4.8

0.3

N.D.

2.1

2.4

N.D. 
tissue in healthy individuals (Löe, Theilade, and Jensen, 1965). In this study, withdrawal of oral hygiene measures in twelve human patients originally having clinically normal gingivae led to the accumulation of soft debris and development of marginal gingivitis in all subjects. Concurrent bacteriological examinations demonstrated an increase in the number of microorganisms in the gingival area and distinct changes in the relative composition of the flora. Reinstitution of oral hygiene resulted in healthy gingival conditions and the reestablishment of the original flora.

While these results do not, by themselves, prove the initiating role of bacteria in periodontal disease,

The fact that . . the change in microflora occurred before gingivitis was clinically diagnosed may indicate that the microorganisms play a role in the initiation of periodontal inflammation. (Lb'e, et al., 1965).

Similar findings relating to an increase in the total numbers of organisms and a relative increase in specific organisms in patients having non-specific gingivitis versus patients with normal gingivae have also been reported (SchultzHaudt, Bruce, and Bibby, 1953).

collagen breakdown by certain enzymes from the gingival bacteria, Bacteroides melaninogenicus has been reported (Macdonald, Gibbons, and Socransky, 1960). Further, it has been demonstrated that hyaluronidase applied locally in the 
gingival sulcus causes a widening of the intercellular spaces of the epithelium (Schultz-Haudt, Dewar, and Bibby, 1963).

Much research has been done concerning the role of bacterial plaque as an essential factor in the initiation of periodontal inflammation. Plaque components have been demonstrated to be nutrients for bacterial growth (Wilderman, 1962). In a study of periodontal disease in dogs, Gad (1968) observed signs of the disease in ninety-seven percent of the dogs, as well as calculus and debris.

A positive correlation between the amount of soft dental deposits and the severity of gingivitis has been demonstrated in the beagle dog (Saxe, Greene, Bohannon, and Vermillion, 1967). The authors found that the etiologic factors in periodontal disease seem to be identical in humans and dogs. In further support of a correlation between bacterial plaque and periodontal disease was the demonstration that a gingivitis which gradually develops into periodontitis can be induced in young beagle dogs simply by allowing plaque to accumulate on the teeth (Iindhe, Hamp, and Löe, 1973). The authors observed three stages in the disease process: 1. Subclinical gingivitis, 2. Clinical gingivitis, 3. Periodontal breakdown. 
The development of a periodontal pathosis associated with the impactation of food and other debris and calculus and plaque has been reported in golden hamsters which had been sustained on a high starch diet (King and Gimson, 194849). In addition, a slowly progressing, insidious inflammatory periodontal breakdown apparently related to the accumulation of plaque and calculus-like accretions has been observed in the Mongolian gerbil. Of relevance to man was the demonstration of many morphological similarities in the periodontal lesion in the two species (Moskow, Wasserman, and Rennert, 1968).

An effective tool in the investigation of the possible roles of specific types of bacteria in periodontal disease has been the antibiotics. These chemotherapeutic agents have been used in the selective elimination from the oral flora of certain bacterial species. Subsequent changes observed in the oral health of the host may suggest a relationship between the type of bacteria which had been eliminated and the changes observed. It has been reported that the administration of either penicillin or streptomycin in the diet of rice rats with periodontal disease resulted in major reductions in the disease in these animals (Gupta, Auskaps, and Shaw, 1957). 
Shaw, Griffiths, and Auskaps, (1961), evaluated the role of antibiotics in periodontal therapy in the rice rat. Two experiments were designed, one to determine the curative ability and the other the preventive ability of four antibiotics administered as a dietary supplement. In experiment one, which was preventive, both high and low concentrations of Erythromycin glucoheptonate resulted in significant prevention of lesions of soft and hard tissues. Two concentrations of Polymixin B sulfate resulted in striking prevention of soft tissue lesions and lesser prevention in hard tissue lesions. In experiment two, which was curative, the animals were maintained for ten weeks on high carbohydrate diet 700 followed by ten weeks of antibiotic supplementation with Benzylpenicillin plus Streptomycin sulfate and Benzylpenicillin plus Oxtytetracycline hydrochloride.

Antibiotic regimens were able to stop the progress of lesions of the calcified tissues but were not adequate to assist in any repair, as they failed to cause regression of bone tissue lesions. In soft tissues they stopped the progress of inflammation and allowed the lesions to heal. At low levels $(.0058-.018)$ Benzylpenicillin and Erythromycin glucoheptonate were effective in prevention while Polymixin B proved ineffective in prevention at these same low levels. These studies indicate a strong microbial 
component in the etiology of the periodontal syndrome of the rice rat.

It has been demonstrated that the microorganisms responsible for the periodontal syndrome in the rice rat are readily transmitted between individuals (Dick and shaw, 1966). The authors obtained results in agreement with those of Gupta et al. (1957) with respect to antibiotic therapy. It was found that rice rats prone to develop periodontal disease when given high carbohydrate diet 700 were rendered relatively inactive with respect to this disease when subjected to a period of penicillin supplementation. After cessation of penicillin administration, inoculation of the oral cavity with organisms from the feces of rats having fully developed periodontal lesions resulted in rapid initiation and progression of the destructive process. Comparable oral inoculation with fecal bacteria of rice rats of the strain which does not develop the disease readily resulted in a greatly increased rate of initiation and progression of lesions. As little as one inoculation on the first day after penicillin cessation was sufficient to result in a return to the same rapid rate of development of the disease as when there had been no suppression of the flora by penicillin. These results, implicating enterococci in the initiation of periodontal disease in the rice 
rat, supported the findings of Macdonald, Socransky, and Sawyer (1960), and Socransky, Macdonald, Sawyer, and Auskaps (1960).

The antibiotic vancomycin, an agent which affects gram-positive bacteria, has been utilized in a study of experimental gingivitis in man (Jensen, Löe, Schiott, and Theilade, 1968). The authors subjected an experimental group to an oral vancomycin rinse for a period of three weeks, assuming this would result in the absence of grampositive bacteria from the oral flora. Both control and experimental groups abstained from any oral hygiene measures during the experimental period. Gingivitis developed in all individuals in the experimental group, implying that the gram-negative flora is able to form plaque and elicit gingivitis in man.

Numerous studies have been conducted implicating various strains of Actinomyces as primary etiologic agents in gingivitis and periodontitis. Keyes and Jordan (1964) demonstrated filamentous bacteria to be an infectious and transmissible component in the causation of periodontal lesions in the Syrian hamster. of the three strains of hamster produced by the NIH Animal Production Center, the golden or syrian, the cream, and the albino, an active type of periodontal disease develops readily in the golden and the 
cream when they are administered a high carbohydrate diet but fails to develop in the albino under similar conditions. In addition, Actinomyces species are found in negligible numbers in the albino hamster. In their research, however, Keyes and Jordan demonstrated that the disease can be induced in non-infected albino animals by inoculation of scrapings of subgingival plaque obtained from infected animals. The disease is then transmitted from generation to generation. Filamentous Actinomyces were found in high numbers in cultures of the plaque material. Significantly, the disease did not develop in uninoculated controls. In a "Generation Study" group, passage of the disease from mother to offspring by coprophagy was investigated. Passage of the disease was terminated by the use of penicillin.

In a related study of gram-positive filamentous bacteria as etiologic agents of experimental periodontal disease in hamsters, Jordan and Keyes (1964) utilized pure cultures of these organisms obtained from the plaque of infected golden and cream hamsters. These cultures were capable of inducing the disease when inoculated orally into uninfected albino hamsters. Other plaque organisms, including streptococci and unidentified gram-negative rods, failed to induce the disease subsequent to similar inoculation of uninfected animals. The periodontal syndrome induced by the 
Actinomyces closely resembled that of the natural infection. The authors concluded that filamentous organisms can be an essential bacterial component in the etiology of periodontal disease in their model.

This conclusion was supported by Socransky, Hubersak, and Propas (1970) who suggested that,
- . certain strains of Actinomyces resident in the human gingival crevice are capable of colonizing the cervical and root surfaces of teeth, of forming destructive bacterial plaques that lead to pocket formation, destruction of alveolar bone, root caries, and exfoliation.

The authors isolated and then cultured 122 bacterial strains from human gingival debris. Nineteen of these formed large amounts of plaque on all test media and proved to be grampositive rods. One strain, Actinomyces naeslundii, was then used in the monoinfection of gnotobiotic Sprague Dawley rats. Four experiments were conducted, the age of the animals at sacrifice ranging from 90 to 455 days. In all cases, experimental animals revealed severe destruction of the alveolar bone associated with subgingival plaque formation, hair impactation, and root caries. Bone loss increment was determined in each experiment. In each case, animals monoinfected with Actinomyces naeslundii demonstrated significantly greater bone loss versus control animals. 
Similar results were obtained by Jordan, Keyes, and Bellack (1972) who inoculated the oral cavities of albino hamsters and gnotobiotic rats with species of Actinomyces of human origin. The gnotobiotic rats, after infection, showed gingival distortion, pocketing, alveoloclasia, and root caries associated with impactation of hair fibers and formation of bacterial mats on root surfaces. The dentition was often destroyed by an invasion of these microorganisms which, in some cases, penetrated to the pulp chamber.

Beveridge and Goldner (1973) sought a statistical relationship between the presence of human subgingival anaerobic diphtheroids and periodontal disease. As a result of assays in periodontal and non-periodontal patients, the amount of anaerobic diphtheroids in the subgingival plaque was determined. The authors found a fifty-nine percent incidence of these organisms in the periodontally diseased patients while the clinically normal individuals showed only four percent.

In a recent assay of human subgingival microflora, it was found that a significantly greater number of Actinomyces was present in the flora of periodontal patients as compared to control subjects (Williams, Pantalone, and Sherris, 1976). 
In an investigation of a limited number of gramnegative bacteria in the healthy and inflamed human gingival crevice, Helderman (1976) observed a significant increase in the proportion of cultivable gram-negative organisms with increasing gingival index score. The organisms implicated were Vibrio sputorum and Fusobacterium nucleatum. These findings seem to refute the previous work of Darwish, Hyyppa, Manganiello, and Socransky (1973) who detected no gram-negative bacteria in a study of the predominant cultivablemicroorganisms in early periodontitis supra and subgingivally. This difference may be reconciled in view of the fact that each study dealt with a different disease state. The former authors obtained data from patients demonstrating gingival inflammation while the latter study dealt with a disease state which included slight bone loss, although both groups had gingivitis.

In the investigation of the presence of specific antigens or antibodies in certain diséase states, agglutination of particulate antigens has been described as a sensitive analytical method. The agglutination test was originally used in the detection of "agglutinin," or antibodies produced as a result of injection of cells or bacteria. Very small quantities of antibody can be detected by this method since only a small number of bivalent antibody mole- 
cules is necessary for the formation of the antigen-antibody lattice (Haurowitz, 1968). The agglutination of bacterial cells has been investigated quantitatively (Heidelberger and Kabat, 1937l.

Antigen-antibody complexes were made visible by the labelling of the antibody molecules with fluorescent compounds in 1956 by Moody, Goldman, and Thomason and Thomason, Moody, and Goldman.

Antigen-antibody reactions which are not always demonstrable by agglutination or other types of serological tests can often by observed by the use of fluorescent antibody techniques (Cherry, Goldman, and Carski, 1960). F.A. techniques have been used in microbiology since the work of Coons in 1942. The value of the F.A. technique as a highly specific method in the identification of bacterial antigens has been demonstrated since the work of Goldman (1953, 1954). The use of fluorescein has been widely indicated for use as a label because its yellow-green color is one to which the eye is most sensitive and in normal tissue is rarely encountered as autofluorescence. In addition, fluorescein is highly efficient (Cherry, Goldman, and Carski, 1960). The isothiocyanate derivative of fluorescein has been used in the labelling of globulins since 1958 (Marshall, Eveland, and Smith, 1958, Riggs, Seiwald, Burck- 
halter, Downs, and Metcalf, 19581.

Actinomyces naeslundii is a gram-positive, pleomorphic, branching, anaerobic rod (Socransky, Hubersak, and Propas, 1970) which is a normal inhabitant of the human oral cavity (Williams, Pantalone, and Sherris, 1976).

Labelled antiglobulins conjugated with FITC were successfully used in the identification of Actinomyces naeslundii and A. israelii by Lambert, Brown, and Georg in 1967. A. naeslundii was found to be serologically distinct from morphologically similar A. israelii. Comparison of F.A. results with those of the agar-gel diffusion test, which was also employed, indicated that the two tests are about equal in sensitivity, but the F.A. test was more specific, since several cross-reactions were encountered with heterologous species in the agar-gel diffusion test, while the F.A. test showed no cross reactions. This serologic characterization of A. naeslundii was supported by Socransky, Hubersak, and Propas in 1970.

The fluorescent antibody technique has been used to identify species of Actinomyces, including A. naeslundii, in human dental plaque by Snyder, Bullock, and Parker (1967). Slack, Mance, and Gerencser (1973) demonstrated that direct F.A. technique can be employed to specifically identify A. naeslundii, among other species in early ( 3 days) and late 
(80 days) plaque.

The further investigation of Blank and Georg (1968) indicated that the fluorescent antibody technique provided rapid and specific identification of several Actinomyces species, including A. naeslundii, both in clinical material and isolated in pure culture.

A. naeslundii has been identified in human dental calculus by the fluorescent antibody technique (Slack, Lanfried, and Gerencser, 1971). In addition, A. naeslundii, as well as $A$. viscosus, has been identified from periodontal pockets (Cummings and Hageage, 1974).

Marttala, Toto, and Gargiulo, (1974) have demonstrated specific antibody activity against $\underline{A}$. naeslundii, A. israelii, A. viscosus, and Streptococcus mitans in the gingiva of patients with chronic periodontal disease.

That specific serum antibodies are produced in patients with periodontal disease has been documented (Nisengard and Beutner, 1970, Gilmour and Nisengard, 1973, Cummings and Hageage, 1974). Experimental ingestion of bacteria in gnotobiotic rats is known to induce specific antibody production in these animals (Michalek, McGhee, Mestecky, Arnold, and Bozzo, 1976).

Both immediate hypersensitivity and the presence of serum antibodies in humans to Actinomyces has been documented 
(Nisengard and Beutner, 1970 a \& b). In addition, the authors found that the percentage of allergic individuals increased with increased severity of periodontal inflammation. Significantly, antibody levels in humans to A. naeslundii and A. israelii were found to increase with increased severity of periodontal inflammation (Nisengard and Beutner, 1970a).

By analysis of sera titers and use of F.A. tests, Gilmour and Nisengard (1973) demonstrated serum antibody activity against A. naeslundii, A. israelii, Bacteronema matruchotti, and Leptotrichia buccalis in patients with gingivitis and periodontitis.

The presence of local antibodies in inflamed human gingiva has been documented (Hartzer, Toto, and Gargiulo, 1971, Byers, 1973, Marttala, Toto, and Gargiulo, 1974).

In a study of the cellular immune response in patients with periodontal disease, Chan, Baker, Mergenhagen, and Socransky (1974) demonstrated the reaction of lymphocytes against A. naeslundii, A. viscosus, A. israelii, and S. mutans.

The antigenic activity of cell portions of A. naeslundii has been demonstrated (Irving, Heeley, and Socransky, 1975). The authors found that intragingival injections of whole dead cells, cell walls, or cytoplasm obtained from A. naeslundii elicited an initial polymorphonuclear response at 
the injection site in all cases. Destruction of osteoblasts of adjacent alveolar bone was also observed for all cell portions. Osteocyte destruction was noted subsequent to whole dead cell or cytoplasm injections but not to cell wall injections. Cell wall injections elicited an early appearance of lymphocytes which "overshadowed" the polymorphonuclear response and persisted up to twenty-four hours post injection, thus suggesting a delayed type hypersensitivity. The destruction of osteoblasts and osteocytes seen after injection of products of A. naeslundii may explain in part the bone loss seen in periodontal disease. 


\section{MATERIALS AND METHODS}

Eight dark-eared, adult albino hamsters, four male and four female, obtained from the Whitney Animal Laboratory, Aurora, N.Y., were used in this experiment. The animals were fed the Cariogenic Test Diet containing 618 sucrose produced by Teklad Test Diets of Madison, Wisconsin. The composition of this diet is given in Table III. All hamsters were given the diet and water ad libitum. The animals were divided into two groups: the control group which consisted of two animals, one male and one female, and the test group, consisting of six animals, three males and three females.

The six animals in the test group were exposed to Actinomyces naeslundii* for a period of 71 days. Actinomyces naeslundii is a gram-positive, pleomorphic, branching, anaerobic rod adaptable to facultative growth (Socransky, Hubersak, and Propas, 1970) and found in negligible numbers in the oral cavity of the albino strain of hamster (Keyes

\footnotetext{
*obtained in lyophilized form from the American Type Culture Collection of Rockville, Maryland.
} 


\section{TABLE III}

\section{Composition of the Test Diet}

\section{CARIOGENIC TEST DIET}

$\mathrm{Gm} \cdot / \mathrm{Kg} \cdot$

Alfalfa leaf meal . . . . . . . 30.0

Milk, powdered whole . . . . . . 350.0

Sucrose . . . . . . . . . . 610.0

Sodium Chloride... . . . . . . 10.0 
and Jordan, 1964l. Exposure to this organism was accomplished by adding one $\mathrm{ml}$. of a pure two-day culture of the organism in trypticase soy broth. In addition, the test animals were exposed directly by application of one $\mathrm{ml}$. of the two-day broth culture to the oral cavity of each animal via pipette. The oral administration was every three days for the first three weeks, after which administration was reduced to once every two weeks. The culture added to the drinking water was replaced every five days with a fresh, pure culture of $\underline{A}_{-}$naeslundii.

The A. naeslundii cultures administered in the experiment were two days old. The cultures were renewed by transfer to fresh sterile trypticase soy broth every five days and checked for purity by gram staining and microscopic inspection.

For purposes of direct oral administration of the test organisms, the experimental animals were anesthetized with diethyl ether in a glass jar of three liter volume (dessicator type).

Application of the test organism consisted in placement of two - four drops $(0.1-0.2 \mathrm{ml})$ of culture to each quadrant of the oral cavity. At each oral administration of the microorganism the hamsters, both test and control, were examined for signs of gingivitis.

A positive sign 
would consist in red, swollen gingiva as seen in the maxillary and mandibular areas.

At the end of the experimental period of 71 days, the blood from test and control animals was obtained. The method of collection was as follows: test animals were anesthetized with diethyl ether. The right brachial artery of each was identified and transected and the blood taken up with a pipette. The blood from the test animals was pooled in a sterile $10 \mathrm{ml}$. centrifuge tube. The same procedure was followed in obtaining the blood of the control group.

The next procedure was serum collection. The blood in each tube (control and test) was centrifuged separately for five minutes at $2000 \mathrm{~g}$ in an International Equipment company Model HN centrifuge. A pipette was then used to take up the supernatant serum. This supernatant was then transferred to another sterile centrifuge tube and the process repeated. These supernatant sera, test and control, were then analyzed for the presence of serum antibodies specific for the test antigen, A. $_{\text {naeslundii. }}$

Two methods were used to determine the presence of antibodies to A. naeslundii in the serum. Serial agglutination was used for rapid, less specific, identification. The fluorescent antibody technique was employed for more specific identification. 
Antigen preparation:

The procedure used in antigen preparation was the same for both the serial agglutination and fluorescent antibody techniques. The supernatant trypticase soy broth was taken up through a pipette, leaving an observable "clump" of $\underline{A}$. naeslundii cells at the bottom of the tube. To the tube was added $5 \mathrm{ml}$. of $0.15 \mathrm{~N}$ phosphate buffered saline solution and the tube was again centrifuged for 3 minutes. The supernatant saline was drawn off with a pipette and $5 \mathrm{ml}$. saline added. This was centrifuged 3 minutes and the saline drawn off, leaving $0.5 \mathrm{ml}$. to suspend the bacterial cells.

\section{Serial agglutination:}

Clean microscope slides were prepared with one drop of the microorganism suspended in the $0.15 \mathrm{~N}$ saline solution. To one drop of the organism in saline was added one drop of serially diluted hamster serum. These dilutions were: $1: 8,1: 16,1: 32,1: 64,1: 128,1: 256,1: 512$, 1:1024. Agglutination was observed as clumping or aggregating of bacteria directly observed through the dark field phase microscope.

2. Fluorescent antibody technique:

Microscope slides were prepared, placing one drop of suspended microorganism on each slide. Two methods were employed to fix bacteria to the slides: air drying and 
heat fixation. One drop $(0.05 \mathrm{ml}$.) of hamster serum was then added to each slide. This procedure was followed in preparing slides with both control and experimental sera, five slides being made with each.

The slides were then incubated at $37^{\circ} \mathrm{C}$ for $35 \mathrm{~min}-$ utes and carefully rinsed in phosphate buffered saline to avoid dislodging the organisms. Then rabbit anti-hamster IgG antiserum conjugated with fluorescein isothiocyanate (FITC)* was applied to the slides and the incubation was continued 35 minutes at $3 f^{\circ} \mathrm{C}$. The slides were then rinsed for three minutes with $0.15 \mathrm{~N}$ phosphate buffered saline. Cover slips were mounted on the slides using a drop of glycerin. Observation for fluorescence of the bacteria was done with fluorescent microscopy**. Photographs were made using color film ASA 164, type B, Kodak***, at 30, 45, and 60 second exposures.

The hamsters were sacrificed by a lethal dose of diethyl ether and a block of the mandible containing the molar teeth of each animal, experimental and control, was resected for histological study. The tissues were fixed in $10 \%$ formalin for 48 hours. They were then washed and dehy-

\footnotetext{
*Microbial Associates, Bethesda, Ma., Cat. \#64-506

** Reichert Zetopan microscope using ultra-violet light source HB200 American Optical, Rochester, N.Y. ***Kodak, Rochester, N.Y.
} 
drated in ascending alcohol concentrations and cleared in xylene. They were then embedded in paraffin. Five representative sections were cut at six microns with an $A$ Rotary 820 microtome from each block, and stained with hematoxylin and eosin. 


\section{CHAPTER IV}

\section{RESULTS}

Fluorescent Antibody Technique

Fluorescence of A. naeslundii, when treated with the serum of experimental animals, was positive, demonstrating the presence of antibodies specific for Actinomyces naeslundii (See Figure 1 and 2). Fluorescence of $\underline{A}$. naeslundii when treated with serum from control animals was negative, indicating the absence of such antibodues in the serum (See Figure 31. A table of results for experimental and control groups is given in Table IV. 


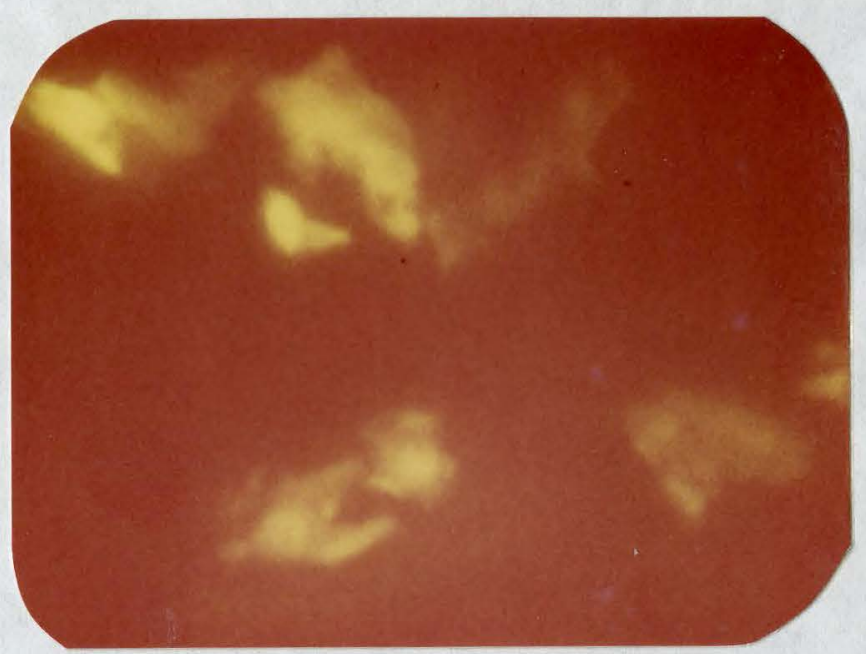

FIGURE 1: A thin smear of a suspension of Actinomyces naeslundii cells in saline solution with hamster serum from experimental animals. This serum had been treated with antihamster IgG bound to fluorescein isothiocyanate (x100). Note the fluorescence of the smear indicating the presence of antibodies in the hamster serum specific for A. naeslundii. 


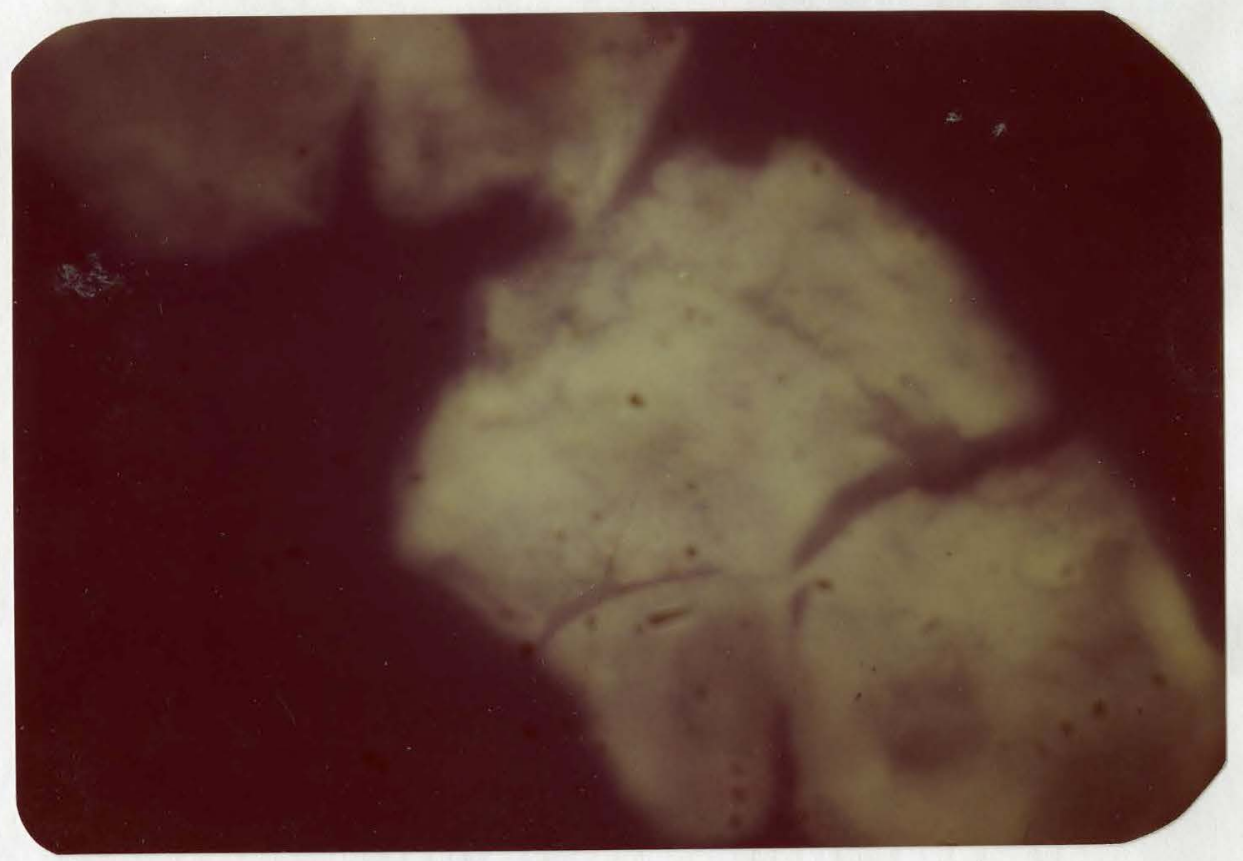

FIGURE 2: Dense smear of $A$. naeslundii cells in saline with hamster antiserum from experimental animals treated with rabbit antihamster IgG immunoglobulin conjugated with FITC (x450).

Note positive fluorescence indicating the presence of antibodies against $\underline{A}$. naeslundii in the hamster serum (See Table IV). 
FIGURE 3: Smear of A. naeslundii in saline with hamster antiserum from control animals treated in a manner identical to that used for the experimental serum: treatment with rabbit antihamster IgG conjugated with FITC (x100). Note negative fluorescence, indicating an absence of antibodies against $A$. naeslundii in the serum of control animals (See Table IV). 


\section{TABLE IV}

Fluorescence of A. naeslundii reacted with serum from experimental and control hamsters.

ANIMALS

Control 1

Control 2

Experimental 1

Experimental 2

Experimental 3

Experimental 4

Experimental 5

Experimental 6
FLUORESCENCE

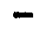

$+$

$+$

$+$

$+$

$+$

$+$ 


\title{
Agglutination
}

Rapid slide agglutination was positive in control animals, demonstrating a titer of 1:256 of antibody in the serum specific for A. naeslundii. Agglutination was negative in control animals, indicating an absence of these antibodies from the serum of these animals (See Table V).

\author{
TABLE V
}

Agglutination of A. naeslundii with serum from control and experimental animals.

ANTIBODY TITER

\begin{tabular}{|c|c|c|c|c|c|c|c|c|}
\hline Animal: & $1: 8$ & $1: 16$ & $1: 32$ & $1: 64$ & $1: 128$ & $1: 256$ & $1: 512$ & $1: 102$ \\
\hline Control 1 & - & - & - & - & - & - & - & - \\
\hline Control 2 & - & - & - & - & - & - & - & - \\
\hline Experimental 1 & + & + & + & + & + & + & - & 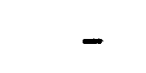 \\
\hline Experimental 2 & + & + & + & + & + & + & - & - \\
\hline Experimental 3 & + & + & + & + & + & + & - & - \\
\hline Experimental 4 & + & + & + & + & + & + & - & 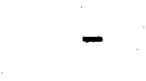 \\
\hline Experimental 5 & + & + & + & + & + & + & - & - \\
\hline Experimental 6 & + & + & + & + & + & + & - & - \\
\hline
\end{tabular}


Histopathology

Observation of histological slides of the mandibles and maxillae of experimental and control animals demonstrated the presence of a basophilic plaque of microorganisms adjacent to the gingival sulcus epithelium in the interproximal areas (See Figure 4).

Signs of an incipient gingivitis were evident upon observation of the histological sections in experimental animals. The lamina propria and basement membrane showed edema, dilated capillaries, and a few polymorphonuclear leukocytes. The PMN's had migrated to the epithelium (See Figures $4,5,6,7)$.

In addition to edema and vasodilation, the lamina propria showed a loss of collagen fibers. Further, the alveolar bone in the crest area showed osteoclastic resorption (See Figures $4,5,8$ ).

Control animals showed normal gingivae with few PMN's in the lamina propria. The alveolar crests of bone showed smooth contour and the epithelium and connective tissue appeared normal. (See Figures 9, 10, 11). 


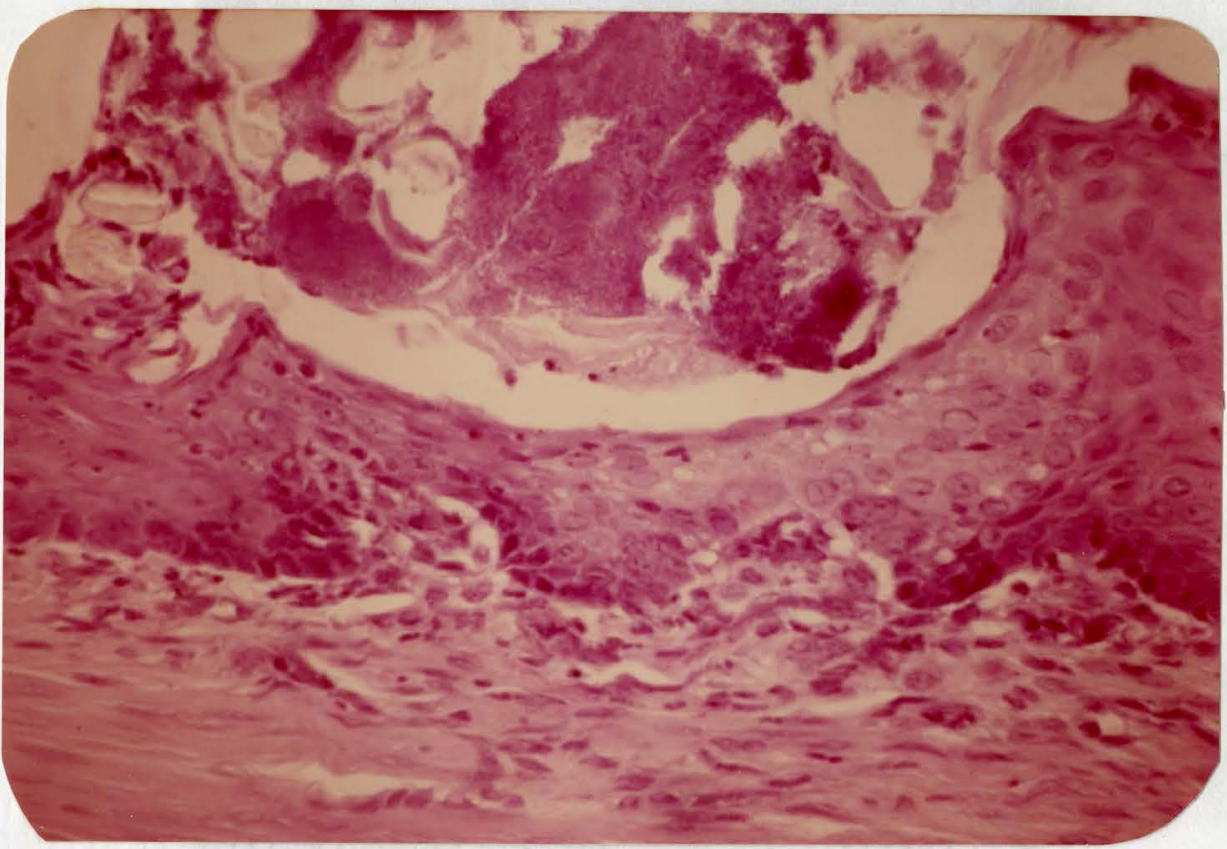

FIGURE 4: Bacterial plaque found on the gingival sulcus epithelium in experimental hamsters $(x 40)$. Note the lamina propria shows edema and dilated capillaries, with a few PMN leukocytes indicative of incipient gingivitis. 


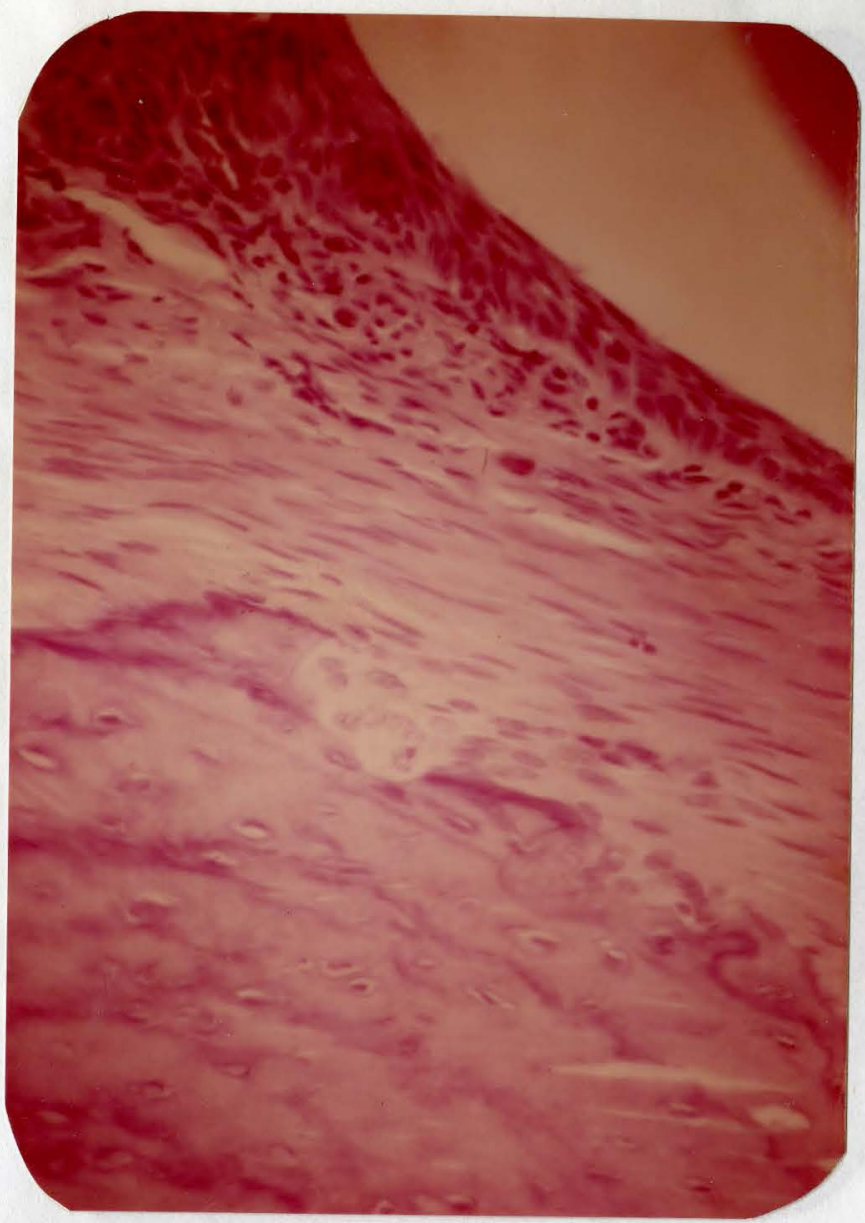

FIGURE 5: Early gingivitis in the hamster subsequent to treatment with A. naeslundii $(x 100)$. Note the edema of the basement membrane, dilated capillaries, and a few PMN leukocytes. There is a dense fibrous lamina propria. The alveolar crest shows osteoclastic resorption. 


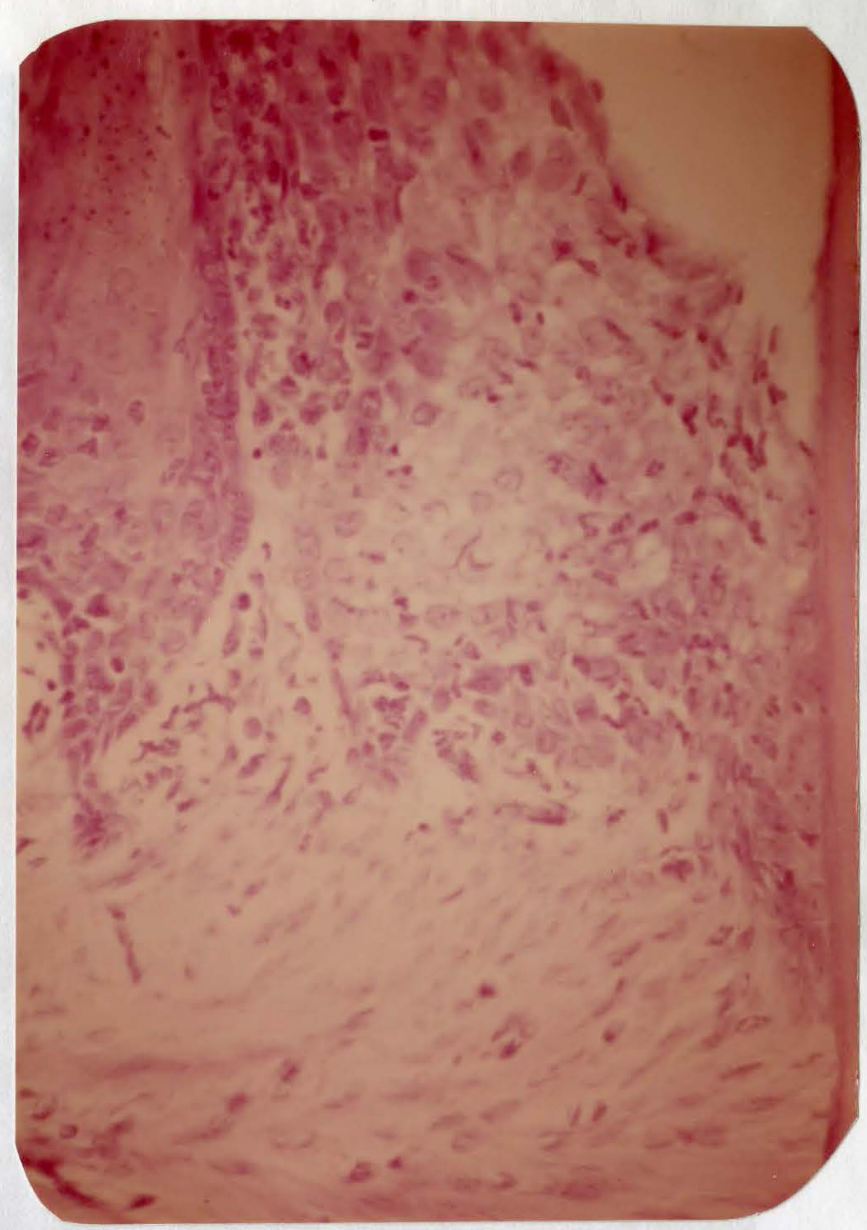

FIGURE 6: Early gingivitis in the hamster showing the interdental papilla of an experimental animal (x100). There is intercellular edema and PMN leukocyte infiltration of the epithelium. The lamina propria shows edema and loss of collagen fibers with the infiltration of a few PMN leukocytes. 


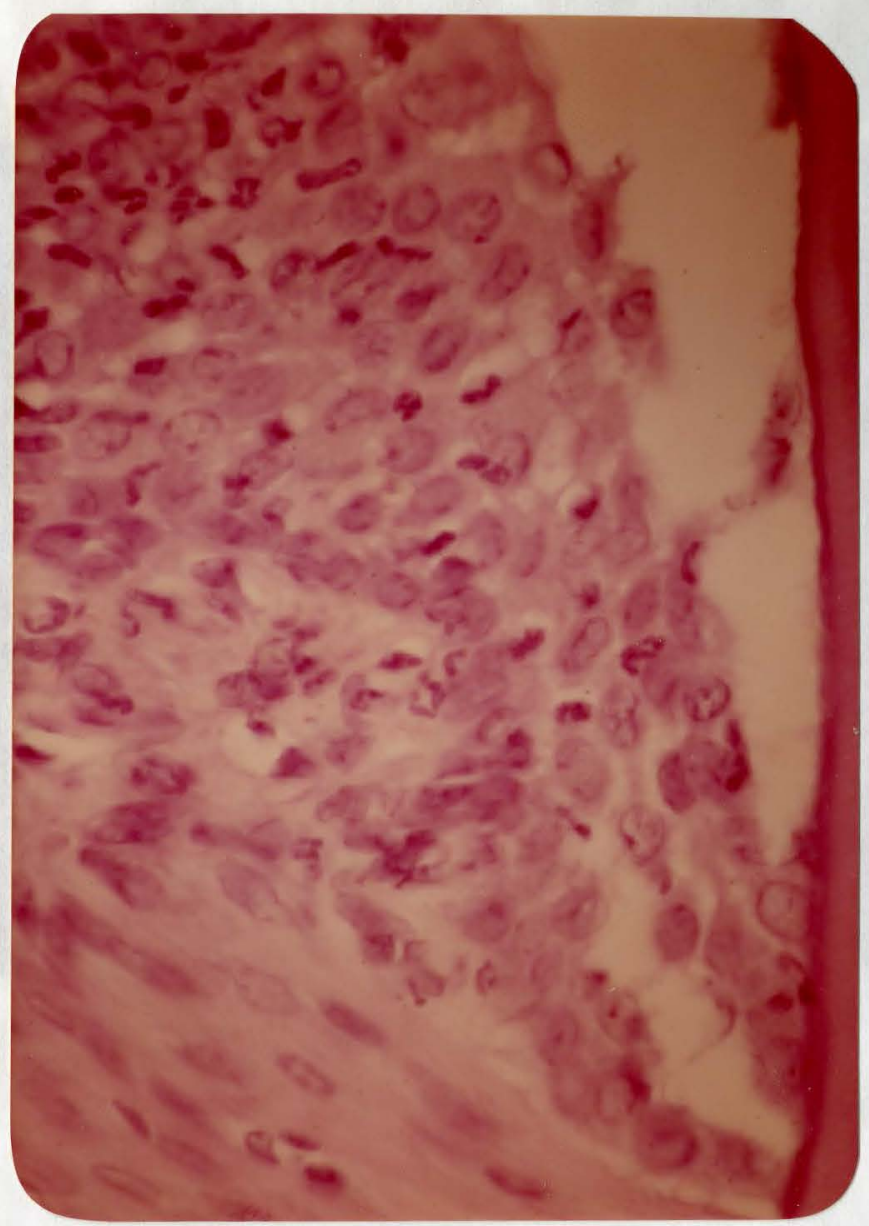

FIGURE 7: High magnification of Figure $6(x 400)$. Note PMN leukocytes and intercellular edema of gingival epithelium. 


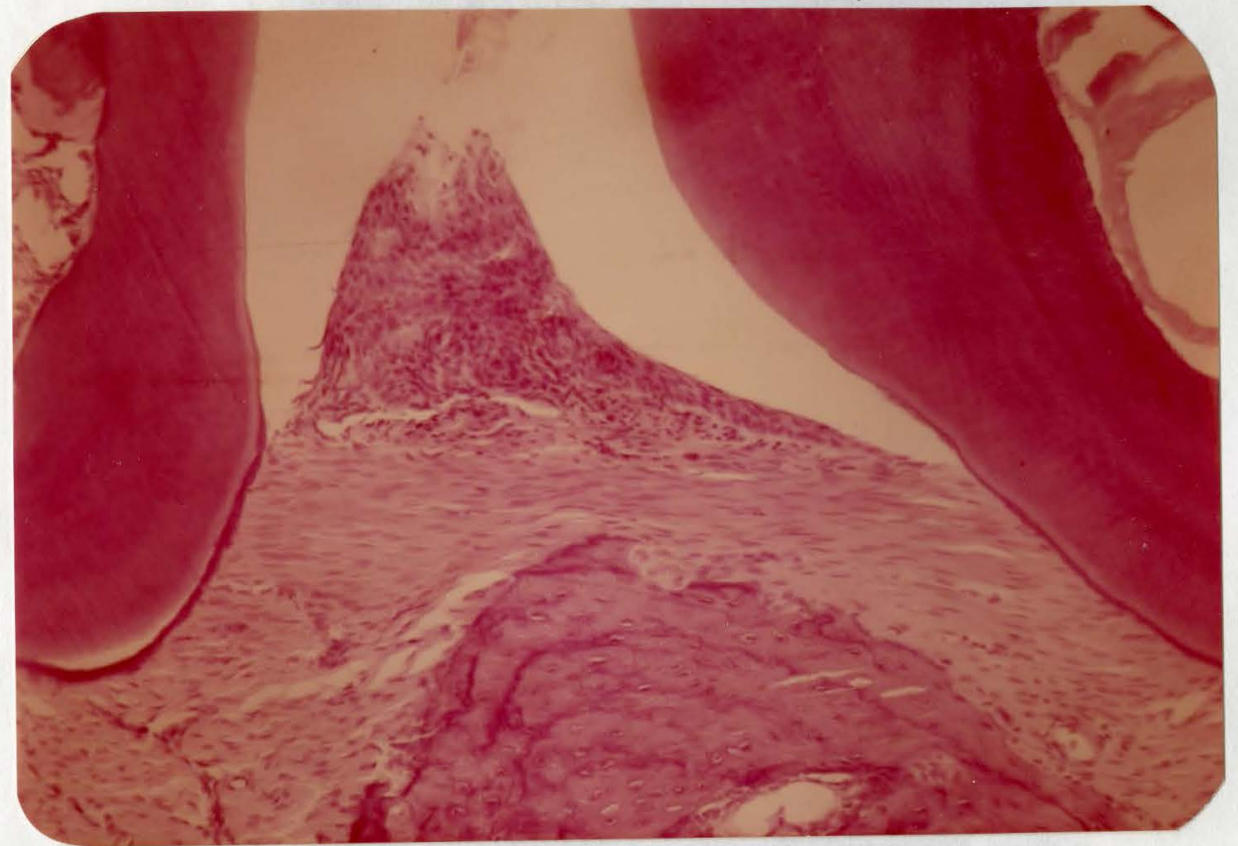

FIGURE 8: Low magnification of Figure 5 (x25). Interdental papilla in an experimental hamster showing gingivitis and alveolar crest bone resorption. 


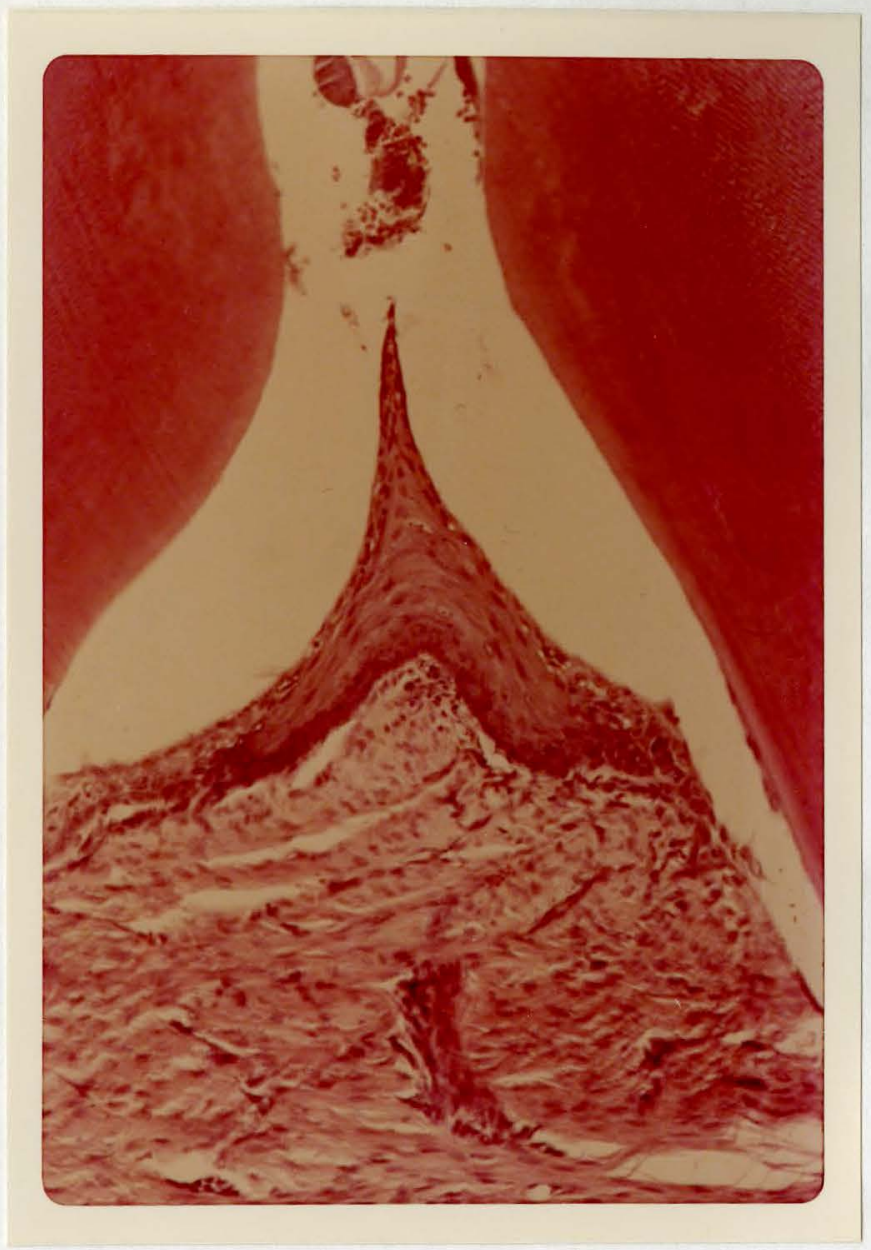

FIGURE 9: Interdental papilla from a control hamster $(\mathrm{x} 40)$, showing normal epithelium and connective tissue. Note few PMN's in the lamina propria and presence of interproximal plaque. 


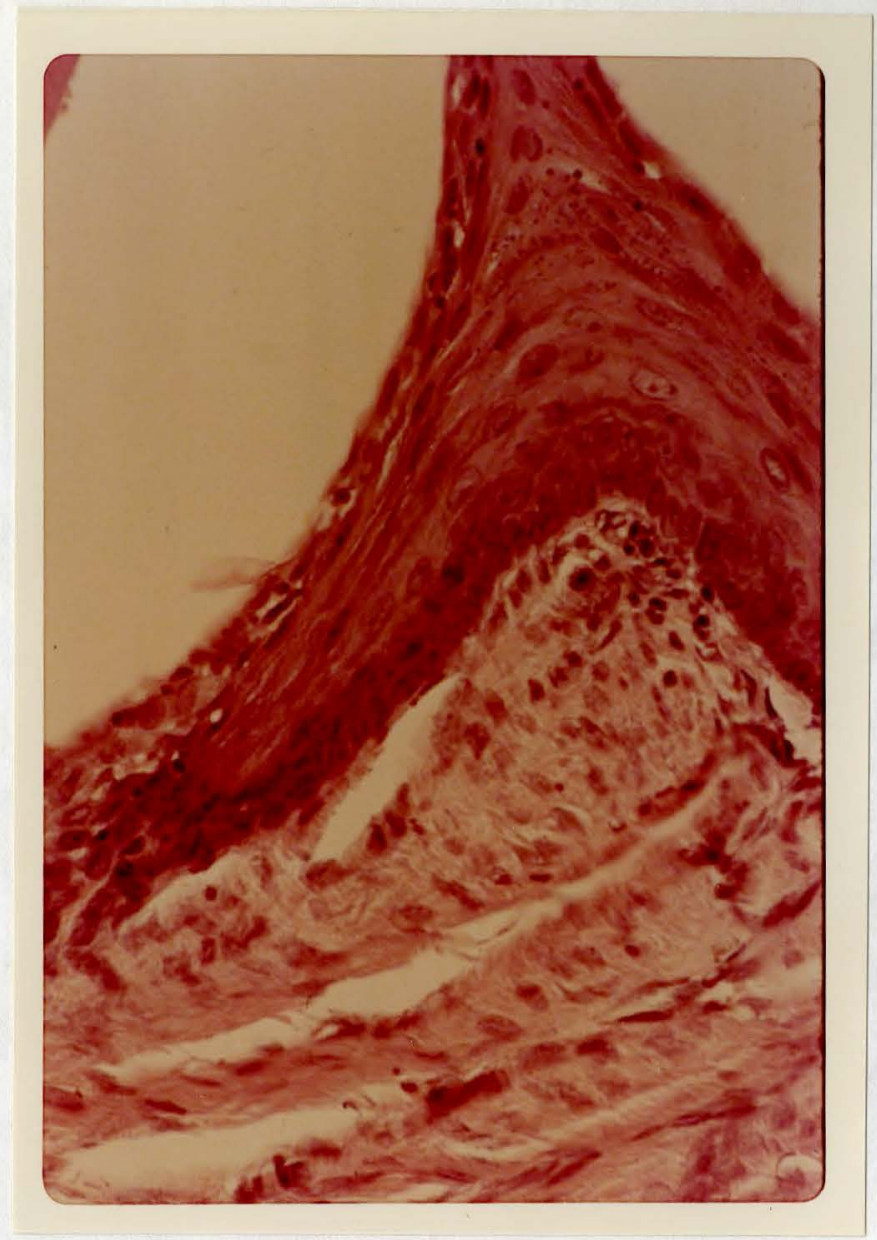

FIGURE 10: High magnification of Figure $9(x 100)$. Note few PMN's in the lamina propria and normal epithelium. 


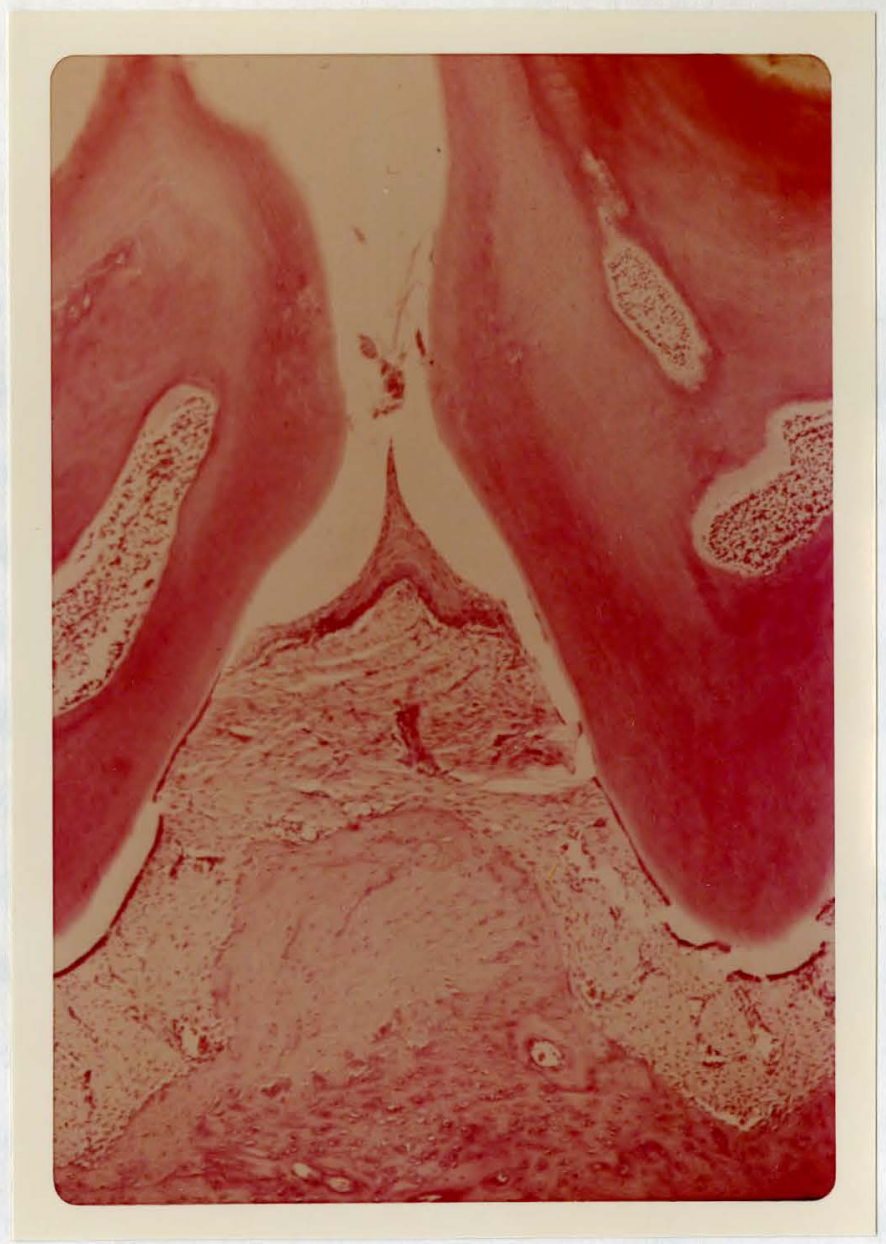

FIGURE 11: Low magnification of Figure 9 (x25). Normal interdental papilla from control hamster. Note smooth contour of the alveolar crest and normal epithelium and connective tissue. 


\section{CHAPTER V}

\section{DISCUSSION}

This study has demonstrated the production of serum antibodies directly specific for Actinomyces naeslundii by albino hamsters subsequent to an oral administration of this microorganism to these animals for a period of 71 days. Histologicallsections taken from the molar areas of the maxillae and mandibles of experimental animals showed the presence of interproximal plaque and an incipient gingivitis.

Interproximal plaque was observed in histological sections taken from the control animals as well. The gingivitis seen in the experimental animals was characterized by intercellular edema and polymorphonuclear leukocytic infiltration. The lamina propria showed edema, loss of the basement membrane, and slight infiltration with PMN leukocytes.

It is probable that the constant challenge to the test animals with $A_{\text {. }}$ naeslundii cells as antigens resulted in an immunological response to this organism in these hamsters. The resulting antibody produced by the host could then lead to the formation of antigen-antibody complexes. These complexes are capable of initiating the complement 
sequence, components of which can release chemical mediators of inflammation (Snyderman, 1973). In addition, these antigen-antibody complexes are directly chemotactic for polymorphonuclear leukocytes (Boyden, 1962), the products of which are known to contribute to tissue destruction (Fel1, Coombs, and Dingle, 1966, Cochrane, 1969l.

Although there have been experiments in the past which have implicated various strains of Actinomyces, includ-

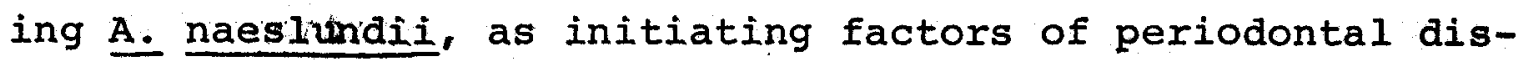
ease in the hamster, none has demonstrated the induced production of serum antibodies specific for an organism which was experimentally introduced into the model under study, this being the main purpose of this investigation. Important circumstances to be considered are: Actinomyces species are found in negligible numbers in the normal oral flora of the albino hamster, the model used in this study (Keyes and Jordan, 1964l; it has been demonstrated that this animal does not develop periodontal disease when subjected to a high carbohydrate diet, unlike the cream and golden strains which do develop the disease under similar circumstances (Keyes and Jordan, 1964).

It has been demonstrated that bacterial plaque is chemotactic for PMN's in vitro, the bacteria being the primary chemotactic factors (Miller, Folke, and Umana, 1975). 
Microscopic observation of the histological sections in this study revealed the presence of a distinct plaque which had formed interstitial to the molar teeth in control and experimental animals. Also in evidence in experimental animals was the presence of a few PMN's in the lamina propria, epithelium, and adjacent to the plaque. This implies the presence of a chemotactic agent in the plaque of experimental animals. It is possible that this agent consists of cells or cell portions of A. naeslundii administered to experimental animals. That certain strains of oral bacteria produce a product directly chemotactic for PMN's is well documented (Walker, Barlet, and Kurtz, 1969, Tempel et al., 1970, Snyderman, 1973, among others).

Wilderman (1962) demonstrated plaque components to be nutrients for bacterial growth. The relationship of plaque to gingival inflammation in experimental animals has been studied at length (Saxe et al., 1967, Gad, 1968, Lindhe et a1., 1973, among others). That an accumulation of bacterial plaque in man is directly correlated with increased gingival inflammation has been shown (Lb̈e, Theilade, and Jensen, 1965).

Gibbons and van Houte (1973) have made the observation that Actinomyces naeslundii forms plaque-like deposits in culture. These cells produce surface constituents which 
impart cohesive properties enabling them to form bacterial masses. Actinomyces colonies form a filamentous "meshwork" which can physically entrap other bacterial species. In addition, certain species of Actinomyces are capable of synthesizing polymers which bind dissimilar organisms. This has been demonstrated by the use of the scanning electron microscope (Jones, 19701. A direct attachment between cells was demonstrated in studies of thin sections by Iistgarten, Mayo, and Amsterdam (1973).

It is indeed probable that certain organisms are able to accumulate in plaque only by means of interspecies interactions because of a lack of alternate adherent mechanisms. The presence of significant numbers of these organisms in plaque would require the proper interacting species to be previously present on the tooth surface. This may be the role of Actinomyces in plaque formation--that of the interacting species. Bladen, Hageage, Pollock, and Harr (1970) reported that Veillonella species were able to attach to preformed plaques formed by $A$. viscosus but that these organisms could not adhere to hard surfaces in vitro. These results may not be conclusive in view of the fact that these hard surfaces were not apatite. Aggregation of cells of Veillonella with suspensions of $A$. viscosus has been observed (Gibbons and Nygaard, 1970). 
It may be by these mechanisms, of antigenicity and plaque formation, that A. naeslundii probably acts as a primary etiological agent in the initiation of gingivitis in albino hamsters (Jordan and Keyes, 1964, Slack, Mance, and Gerencser, 1973, Irving, Heeley, and Socransky, 1975). The incipient gingivitis found in experimental animals in this investigation was similar to that reported by Miller and Ripley (1975) in their study of early periodontal disease in the Syrian hamster. The authors inoculated experimental animals with A. naeslundii, using a method similar to that of the present investigation. In addition, the diet used, diet 2000, containing 568 sucrose, (Keyes and Jordan, 1964) was similar to that of the present study. Jordan and Keyes (1964) observed an induction of gingivitis after a 71 day period in albino hamsters inoculated with a labelled strain of Actinomyces. This strain was recovered from the plaque of experimental animals upon termination of the investigation. The development of an incipient gingivitis in experimental hamsters after a 71 day test period in this investigation supports the findings of their experiment. Diet 2000, used in their study and similar to that used in this investigation, was successful in supporting the implantation of this labelled strain of Actinomyces in albino hamsters. 
Not observed in this investigation were the changes grossly apparent in the periodontium of experimental animals reported by Socransky, Hubersak, and Propas (1970), who experimentally induced periodontal disease in germfree Sprague Dawley rats by a monoinfection with $A$. naeslundii. One possible reason for the difference in severity between the two experiments is the length of the test period. The test period in this investigation was 71 days, while socransky et al. ran experiments ranging from 90 to 455 days. It may be that the incipient nature of the disease seen in this experiment was due to the relatively short test period. This is plausible in view of the fact that the gingivitis in this investigation was similar to that found by Miller and Ripley (1975) in the syrian hamster over a similar test period. However, another possible reason for the incipient nature of the disease seen in the test animals in this investigation is the possibility that the repeated exposure to the test antigen induced a sensitization in these animals, the antibody produced serving an immunologic function in defense of the host and preventing a progression of the gingivitis. The use of fluorescently labelled rabbit anti-hamster IgG immunoglobulin, in this experiment, proved to be successful in the identification of antibodies specific for A. naeslundii in the serum of albino hamsters previously 
infected experimentally with this organism. The use of A. naeslundil as an antigenic agent to challenge albino hamsters was effective in inducing the production of serum antibodies in the host specific for this organism, thus eliciting an immune response in these animals.

The fluorescent antibody technique is a highly reliable and specific method of identification of antigenantibody complexes which are often not demonstrable by means of agglutination or other types of serological tests (Cherry, Goldman, and Carski, 1960). Fluorescent antibody techniques have been used with consistent success in the identification of bacterial antigens since 1953 (Goldman, 1953 and 1954). The isothiocyanate derivative of fluorescein, the label used in this investigation, has been effectively used in the labelling of globulins since 1958 (Marshall, Eveland, and Smith, 1958, Riggs, Seiwald, Burckhalter, Downs, and Metcalf, 1958).

The successful employment of antiglobulins labelled with FITC in the identification of A. naeslundii in this study confirms the observations of Lambert, Brown, and Georg (1967). Significantly, the authors found A. naeslundii to be serologically distinct from morphologically similar A. israelii and demonstrated the fluorescent antibody test to be more specific than the agar-gel diffusion 
test. The characterization of $A$. naeslundii as serologically distinct was supported in 1970 by Socransky et al. The albino hamsters in this study, both control and experimental, were seen to develop an interproximal plaque resulting from a high sucrose diet and, in experimental animals, oral administration of A. naeslundii. It is possible that the plaque of experimental animals contained A. naeslundii cells, considering that such implantation of Actinomyces in the plaque of albino hamsters has been documented (Jordan and Keyes, 1964). A. naeslundii has been specifically identified in dental plaque by the use of fluorescent antibody (Snyder, Bullock, and Parker, 1967, Slack, Mance, and Gerencser, 1973).

In this investigation, a production of serum antibodies in albino hamsters specific for A. naeslundii was demonstrated. This observation supports the findings of Nisengard and Beutner (1970), Gilmour and Nisengard (1973), and Cummings and Hageage (1974), in human patients with periodontal disease. In addition, this study strengthens the observations of Michalek et al. (1976), who demonstrated that the experimental ingestion of bacteria in gnotobiotic rats results in a production of specific antibodies in these animals. 
This serum antibody production is a result of the antigenic nature of the cells of Actinomyces naeslundii. The possible routes of entry of such antigens could be the gingiva (Marttala, Toto, and Gargiulo, 1974) and the gastrointestinal tract as reported by Michalek et al. (1976).

The results of this investigation support the findings of Irving, Heeley, and Socransky (1975), who reported antigenic activity on the part of cell portions of A. naesIundii.

Anaerobic culturing in trypticase soy broth provided for adequate growth of the bacterial cultures required in this investigation. This was observed as rapid growth to turbidity in the broth tubes. The water bottles of experimental animals became turbid subsequent to the addition of the pure broth culture of Actinomyces naeslundii. The water bottles of the control group, however, remained clear. This supports the observations of Socransky, Hubersak, and Propas (1970) who characterized A. naeslundii as being adaptable to facultative growth.

Rapid slide agglutination, using serum serially diluted, proved to be a reliable method for the determination of a serum antibody titer. The dark field phase microscope provided a useful means of observation of bacterial clumping . 
In preparation of FA slides, heat fixation proved to be superior to air drying in fixing the bacteria to the slides.

This investigation points toward further studies of the immunological mechanisms involved in antigen-host interaction. In particular, further investigation of the specific antigenic portions of bacterial cells and their interaction with the host immune system is indicated. The role of hypersensitivity in gingival disease, not yet fully understood, must also be studied. Furthermore, the defensive role of antibodies formed against plaque bacteria in patients free of periodontal disease should be investigated. 


\section{CHAPTER VI}

\section{SUMMARY AND CONCLUSIONS}

Actinomyces naeslundil from a broth culture was prepared as a smear on slides and reacted with antiserum obtained from six albino hamsters previously inoculated with A. naeslundil and having gingivitis. Smears were also prepared with serum from two uninoculated albino hamsters having normal gingivae. The treated smears were reacted with rabbit antihamster antiserum to the immunoglobulin IgG conjugated with fluorescein isothiocyanate. The slides were then examined microscopically for immunofluorescence with a fluorescent microscope with an ultraviolet light source. Fluorescence was positive to Actinomyces naeslundii in the serum of experimental animals and negative in the controls. A. naeslundii from a broth culture was prepared as a smear on slides and reacted with antiserum obtained from the six experimental and two control animals serially diluted. The slides were observed through a dark field microscope for agglutination of the bacteria. Agglutination was positive in the experimental animals with a serum titer of 1:256 and negative in the controls. 
A block of the mandibles and maxillae containing the teeth of each animal was resected for histologic study. Observation of slides made from these sections showed the presence of interproximal plaque in both control and experimental animals. Signs of an incipient gingivitis were evident in experimental animals.

In experimental animals, the lamina propria and basement membrane showed edema, dilated capillaries, and a few polymorphonuclear leukocytes. The PMN's had migrated to the epithelium. The bone of the alveolar crest showed osteoclastic resorption.

Heat fixation proved to be a better method than air drying for fixing the bacteria to the slides. The bacterial cells showed better retention using heat fixation. The following can be concluded from this study:

1. Animals treated with Actinomyces naeslundii via oral inoculation, developed an incipient gingivitis.

2. The challenge of Actinomyces naeslundii induced the production of serum antibodies specific for this organism in experimental animals. Control animals demonstrated no antibody production against A. naeslundii.

3. Heat fixation is superior to air drying for purposes of retaining the bacteria to the slide. 


\section{BIBLIOGRAPHY}

Arnim, S.S. "Antony van Leeuwenhoek, the First Periodontist," Ac. Rev. of the Acad. Perio., July. 3, 1967.

Bahn, A.N. "Microbial Potential in the Etiology of Periodontal Disease," J. Periodont., 41: 603-10, 1970.

Baram, P, and Arnold, L. "Immunologic Aspects of Periodontal Disease," J. Periodont., 41: 617-19, 1970.

Beveridge and Goldner, M. "Statistical Relationship Between the Presence of Human Subgingival Anaerobic

Diphtheroids and Periodontal Disease," J." Dent. Res., 52: 451-53, Jan.-June, 1973.

Bladen, Hageage, H.G., Pollock, F., and Harr, R. "Plaque Formation in Vitro on Wires by Gram-Negative Oral Microorganisms (Veillonella)," Arch. Oral Biol., 15: $127,1970$.

Blank, C.H. and Georg, I.K. "The Use of Fluorescent Antibody Methods for the Detection and Identification of Actinomyces Species in Clinical Material," J. Lab and Clin. Med., 71: 283-93, 1968.

Boyden, S.V. "The Chemotactic Effect of Mixtures of Antibody and Antigen on Polymorphonuclear Leukocytes," J. Exp. Med., 115: 453, 1962 .

Burnett, G.W. and Scherp, H.W. Oral Microbiology and Infectious Disease: A Textbook for students and practitioners in Dentistry. 3rd ed. Baltimore: Williams and WiIkins Co., 1968.

Byers, C.N. "Levels of the Immunoglobulins IgA, IgG, and IgM in the Inflamed Human Gingiva." Master's Thesis, Loyola University School of Dentistry, 64 pages, 1973.

Chan, S.P., Baker, J.J., Mergenhagen, S.E., and Socransky. S.S. "Lymphocyte Stimulation by Oral Bacterial Antigens," Abst. \#329, J. Dent. Res., 53: 137, 1974. 
Cherry, W.B., Goldman, Sc. D., and Carski, T.R. "Fluorescent Antibody Techniques in the Diagnosis of Communicable Diseases," U.S. Dept. of Health, Ed., and Welfare, Public Health Service, Bureau of State Services Communicable Disease Center, Atlanta, Ga., Publication $\# 729$, 1960 .

Cochrane, C.G. and Dixon, F.J. "Cell and Tissue Damage Through Antigen-Antibody Complexes," In Textbook of Immunopathology, pp. 94-100, 1969.

Cohn, Z.A, and Hirsch, J.G. "The Isolation and Properties of the Specific Cytoplasmic Granules of Rabbit Polymorphonuclear Leukocytes," J. Exp. Med., 112: 983-1004, 1960 .

Coons, A.H., Creech, H.J., Jones, R.N., and Berliner, E. "The Demonstration of Pneumococcal Antigen in Tissues By the Use of Fluorescent Antibody," J. Immunol., 45: $159-170,1942$.

Cummings, N.A. and Hageage, C.J. "Antibodies to Actinomyces viscosus in the Serum and Gingiva Extract of a Patient With Severe Periodontal Inflammation," Abst. \#330, J. Dent. Res., 53: 137, 1974.

Darwish, S., Hyyppa, T., Manganiello, A.D., and Socransky, S.S. "Predominance of Cultivable Microorganisms in Periodontitis and Periodontosis," II, Early Periodontitis, Abst. \#289, J. Dent. Res., 52: 131, 1973.

Dick, D.S. and Shaw, J.H. "The Infectious and Transmissible Nature of the Periodontal syndrome of the Rice Rat," Arch. Oral Biol., 11: 1095-1108, 1966.

Dumonde, D.C., Howson, W.J., and Wolstencroft, R.A. "Fifth International Symposium on Immunopathology" (ed. R.A. Miescher, P. Grabar.) New York: Grune and Stratton, Inc., p. 263, 1967.

Ellison, S.A. "Oral Bacteria and Periodontal Disease," J. Dent. Res., 49: 198-200, 1970 . 
Fell, H.B., Coombs, R.R., and Dingle, J.T. "The Breakdown of Embryonic Cartilage and Bone Cultivated in the Presence of Complement-Sufficient Anti-serum...." Int. Arch. Allergy Appl. Immunol., 30: 146, \#2, 1966.

Frenkel, J.K. Pathology Society Symposium on Choice of Animal Models for the Study of Disease Processes in Man, Introduction, Fed. Proc., 28: 160-215, 1969.

Gad, T. and Langebaek, J. Paradontalbehandling af Furkaturinvolverede Taender, Tandlaegebladet 72: 331-40, April 1968 (Dan.l

Gibbons, R.J. and Nygaard, M. "Interbacterial Aggregation of Plaque Bacteria," Archs. Oral Biol., 15: 1397, 1970.

Gibbons, R.J. and Van Houte, J. "On the Formation of Dental Plaques," J. Periodont., 44: 347-60, 1973.

Gilmour, M.N. and Nisengard, R.J. "Sera Titers to Filamentous Bacteria and Relation to Periodontal Disease," Abst. \#333, J. Dent. Res., 52: 142, 1973.

Goldman, M. "Cytochemical Differentiation of Endamoeba Histolytica and Endamoeba coli by Means of Fluorescent Antibody," Am. J. Hyg., 58: 319-28, 1953.

Goldman, M. "Use of Fluorescein-tagged Antibody to Identify Cultures of Endamoeba Histolytica and Endamoeba coli," Am. J. Hyg., 59: 318-25, 1954 .

Green, J.A., Cooperband, S.R., Rutstein, J.A., and Kibrick, S. "A Lymphocyte-produced Factor which Inhibits Proliferation of Other Cells," Fed." Proc., 29: 306, 1970.

Gupta, O.P., Auskaps, A.M., and Shaw, J.H. "Periodontal Disease in the Rice Rat IV: The Effects of Antibiotics on the Incidence of Periodontal Lesions," Oral Surg.. 10 : 1169-1175, 1957 .

Hartzer, R.C., Toto, P.D., and Gargiulo, A.W. "Immune Reactions in the Gingiva of the Pregnant and Nonpregnant Human Female," J. Periodont., 42: 239-45, 1971.

Haurowitz, F. Immunochemistry and the Biosynthesis of Antibodies. N.Y., London, Sydney: John Wiley and Sons, p. 139, 1968. 
Heidelberger, M. and Kabat, E.A. "Chemical Studies on Agglutination," J. Exp. Med., 65: 885, 1937.

Helderman, W.H. van P. "Total Viable Count and Differential Count of Vibrio Sputorum, Fusobacterium Nucleatum, Selenomonas Sputigena, Bacteroides Ochraceus, and Veillonella in the Inflamed and Non-inflamed Human Gingival Crevice," J. Periodontal Res., 10: 294-305, 1976.

Hill, J. and Ward, P.A. "C3 Leukotactic Factors Produced by a Tissue Protease," J. Exp. Med., 130: 505, Sept. 1, 1969.

Hook, W.A., Snyderman, R., and Mergenhagen, S.E. "HistamineReleasing Factor Generated by the Interaction of Endotoxin with Hamster Serum," Infect. Immunity, 2: 462, Oct. 1, 1970.

"Further Characterization of a Factor From Endotoxin-Treated Serum Which Releases Histamine and Heparin from Mast Cells," Infect. Immunity, 5: 909, \#6, 1972 .

Horton, J.E., Leikin, S., and Oppenheim, J.J. "Human Lymphoproliferative Reaction to Saliva and Dental Plaque Deposits: An In-Vitro Correlation With Periodontal Disease," J. Periodontol., 43: 522, Sept., 1972.

Horton, J.E., Oppenheim, J.J., and Mergenhagen, S.E.

"Elaboration of Lymphotoxin by Cultured Human Peripheral Blood Leukocytes Stimulated With Dental Plaque Deposits," Clin. Exp. Immunol., 13: 383, March 1, 1973.

Horton, J.E., Raisz, L.G., Simmons, H.A., Oppenheim, J.J., and Mergenhagen, S.E. "Bone Resorbing Activity in Supernatant Fluid from Cultured Human Peripheral Blood Leukocytes," Science, 177: 793, Sept. 1, 1972.

Irving, J.T., Heeley, J.D., and Socransky, S.S. "Cellular Response to Subgingival Injection of Bacterial Products in the Rat," J. Periodontal Res., 10: 324-31, 1975.

Ivanyi, L. and Lehner, T. "Stimulation of Lymphocyte Transformation by Bacterial Antigens in Patients with Periodontal Disease," Arch. Oral Biol., 15: 1089, Nov., 1970. 
Jensen, J. "Anaphylation in its Relation to the Complement System," Science, 155: 1122, March 3, 1967.

Jensen, S.B., Lbe, H.E., Schiott, R., and Theilade, E. "Experimental Gingivitis in Man," IV, J. Periodontal Res., 3: 284-93, 1968 .

Jensen;, S.B. and Mergenhagen, S.E. "Influence of Endotoxins on the Dermal Response of Rabbits to Human Oral Bacteria," Arch. Oral Biol., 9: 241-54, 1964.

Jensen, J., Snyderman, R., and Mergenhagen, S.E. Chemotactic Activity, a Property of Guinea Pig C5 Anaphylatoxin, Proceedings of the Third International Symposium on Cellular and Humoral Mechanisms of Anaphylaxis and Allergy, Base1, Switzerland, Karger, p. 265, 1969.

Jones, S.J. "Natural Plaque on Tooth Surfaces: A Scanning Electron Microscopy Study," Apex, J.U. College Hosp., Dent. Soc., 5: 93, 1971

Jordan, H.V. "Rodent Model Systems in Periodontal Disease Research," J. Dent. Res., 50: 236-42, 1971.

Jordan, H.V. and Keyes, P.H. "Aerobic, Filamentous Bacteria as Etiologic Agents of Experimental Periodontal Disease in Hamsters," Arch. Oral Biol., 9: 401-14, 1964.

Jordan, H.V., Keyes, P.H., and Bellack, S. "Periodontal Lesions in Hamsters and Gnotobiotic Rats Infected with Actinomyces of Human Origin," J. Periodontal Res., 7: 21: 1972 .

Jordan, H.V., Keyes, P.H., and Lim, S. "Plaque Formation and Implantation of Odontomyces Viscosus in Hamsters Fed Different Carbohydrate Diets," J. Dent. Res., 48: 824, 1969 .

Keller, H.J. and Sorkin, E. "Studies on Chemotaxis," V, Int. Arch. Allergy Appl. Immunol., 31: 505, 1967.

Keyes, P.H. and Fitzgerald. "Dental Caries in the Syrian Hamster-X," Int. Dent. J., 13: 86-109, 1970.

Keyes, P.H. and Jordan, H.V. "Periodontal Lesions in the Syrian Hamster-III," Arch. Oral Biol., 9:377-400, 1964. 
King, J.D. and Gimson, A.R. "Lesions of the Gum and Alveolar Bone," Brit. J. Nutr., 2: 111-18, 1948-49.

Klinkhamer, J.M. "Quantitative Evaluation of Gingival and Periodontal Disease," Periodont., 6: 207-11, 1968.

Krygier, G.; Genco, R.J., Mashino, P.A., and Hausmann.

"Experimental Gingivitis in Macaca Speciosa Monkeys:

Clinical, Bacteriologic, and Histological Similarities

to Human Gingivitis," J. Periodonto1., 44: 454, 1973.

Lambert, F.W., Brown, J.M., and Georg, L.K. "Identification of Actinomyces israelii and $A$. naeslundii by Fluorescent Antibody and Agar-gel Diffusion Techniques," Bacteriology, 94: 1287-95, 1967.

Lindhe, J., Hamp, S.E., and Löe, H. "Experimental Periodontitis in the Beagle Dog," J. Periodontal Res., 8: 1-10, 1973 .

Listgarten, M.A., Mayo, H., and Amsterdam, M. "Ultrastructure of the Attachment Device Between Coccal and Filamentous Microorganisms in 'corn cob' Formations of Dental Plaque," Archs. Oral Biol., 17: 651-56, 1973.

Löe, H., Theilade, E., and Jensen, S.B. "Experimental Gingivitis in Man," J. Periodontol., 36: 177-87, 1965.

Macdonald, J.B., Gibbons, R.J., and Socransky, S.S. "Bacterial Mechanisms in Periodontal Disease," Ann. N.Y. Acad. Sci., 85: 467, 1960 .

Macdonald, J.B., Socransky, S.S., and Sawyer, S.J." "Pathogenicity Experiments with the Flora of the Periodontium in Rice Rats," J. Dent. Res., 39: 861, 1960.

Macdonald, J.B., Socransky, S.S., and Sawyer, S.J. "Survey of the Bacterial Flora of the Periodontium in the Rice Rat," Archs. Oral Biol., 1: 1-7, 1959.

Marshall, J.D. Jr., Eveland, W.C., and Smith C.W. "Superiority of Fluorescein Isothiocyanate (Riggs) for Fluorescent Antibody Technique with a Modification of its Application," Proc. Soc. Exper. Biol. \& Med., 98:898-900, 1958. 
Marttala, W.H., Toto, R.D., and Gargiulo, A.W. "Identification of Fluorescent Antibodies in Periodontitis," J. Periodontol. 45: 853-61, 1974 .

Mergenhagen, S.E. "Nature and Significance of Somatic Antigens of Oral Bacteria," J. Dent. Res., 46: 46, 1967.

Michalek, S.M., MC Ghee, J.R., Mestecky, J., Arnold, R.R., and Bozzo, L. "Ingestion of Streptococcus mutans

Induces Secretory Immunoglobuiin A and Caries Immunity," Science, 192: 1238-40, 1976 .

Miller, R.I., Folke, L.E.A., and Umana, C.R. "Chemotactic Ability of Dental Plaque Upon Autologous or Heterologous Human Polymorphonuclear Leukocytes," J. Periodontol., 46: 409-14, 1975.

Miller, W.A. and Ripley, J.F. "Early Periodontal Disease in the Syrian Hamster," J. Periodontol., 46: 368-74, 1975.

Moody, M.D., Goldman, M., and Thomason, B.M. "Staining Bacterial Smears with Fluorescent Antibodies I. General

Methods for Malleomyces pseudomalleii," J. Bact., 72: $357-61,1956$.

Moskow, B.S., Wasserman, B.H., and Rennert, M.C. "Spontaneous Periodontal Disease in the Mongolian Gerbil," J. Periodontol. Res., 3: 69, 1968.

Movius, D.L., Rogers, R.S. III, and Reeve, C.M. "Lymphocytotoxicity for Gingival Epithelial Cells in Periodontal Disease," J. Periodontol., 46: 271-76, 1975.

Nisengard, R.J. and Beutner, E.H. "Immunologic Studies of Periodontal Disease V. IgG Type Antibodies and Skin Test Response to Actinomyces and Mixed Oral Flora," J. Periodontol., 41: 149-52, 1970a.

"Relation of Immediate Hypersensitivity to Periodontitis in Animals and Man," J. Periodontol.. 41 : $223-27$, $1970 \mathrm{~b}$.

Oppenheim, J.J. "Immunological Relevance of Antigen and Antigen-Antibody Complex Induced Lymphocyte Transformation," Ann. Allergy, 27: 305, July, 1969. 
Papermaster, D. "Immunoglobulins," In Monograph on Immunology, p. 11, Kalamazoo, Mich.: The Upjohn Co.. 1972.

Pick, E. and Turk, J.L. "The Biological Activities of Soluble Lymphocyte Products," Clin. Exp. Immunol., 10: 1, Jan., 1972.

Riggs, J.I., Seiwald, R.J., Burkhalter, J., Downs, C.M., and Metcalf, T.G. "Isothiocyanate Compounds as Fluorescent Labeling Agents for Immune Serum," Am. J. Path., 34 : 1081-97, 1958 .

Rizzo, A.A. "Periodontal Disease Research, Introductory Remarks," J. Amer. Dent. Assoc., 87: 1019, 1973.

Rovin, S., Costich, E.M., and Gordon, H.A. "The Influence of Bacteria and Irritation on the Initiation of Periodontal Disease in Germ-free and Conventional Rats," J. Periodont. Res., 1: 193, 1966.

Saxe, S.R., Greene, J.C., Bohannon, H.M., and Vermillion, J.R. "Oral Debris, Calculus, and Periodontal Disease in the Beagle Dog," Periodontics, 5: 217, 1967.

Schultz-Haudt, S., Bruce, M.A., and Bibby, B.G. "Bacterial Factors in Nonspecific Gingivitis," J. Dent. Res., 32: 681, Oct., 1953, Abst. \#117.

Schultz-Haudt, S., Dewar, M., and Bibby, B.G. "Effects of Hyaluronidase on Human Gingival Epithelium," Science, 117: $653,1963$.

Schwartz, J. and Diblee, M. "The Role of IgE in the Release of Histamine from Human Gingival Mast Cells," J. Periodontol., 46: 171-77, 1975a.

"The Effect of Endotoxins and Enzymes in Vitro on the Release of Gingival Histamine," J. Periodontol., 46 : 662-68, 1975b.

Seyle, H. The Mast Cells. Washington, D.C.: Butterworth and $\mathrm{Co}_{.} \mathrm{1} \overline{965}$.

Shaw, J.H., Griffiths, D., and Auskaps, A.M. "Influence of Antibiotics on the Periodontal syndrome in the Rice Rat," J. Dent. Res., 40: 511-19, 1961. 
Slack, J.M., Lanfried, S., and Gerencser, M.A. "Identification of Actinomyces and Related Bacteria in Dental Calculus by the Fluorescent Antibody Technique," J. Dent. Res., 50: 78-82, 1971.

Slack, J.M., Mance, T., and Gerencser, M.A. "Fluorescent Antibody and Microscopic Counts of Filamentous Bacteria in Plaque," Abst. \#155, J. Dent. Res., 52: 96, 1973.

Snyder, M.I., Bullock, W.W., and Parker, R.B. "Morphology of Gram-Positive Filamentous Bacteria in Dental Plaque by Fluorescent Antibody Technique," Arch. Oral Biol.. 12: 1269-73, 1967.

Snyderman, R. "Immunological Mechanisms of Periodontal Tissue Destruction," J. Amer. Dent. Assoc., 87: 1020-26, 1973.

Snyderman, R., Phillips, J.K., and Mergenhagen, S.E. "Biological Activity of Complement in Vivo: Role of C5 in the Accumulation of PMN's in Inflammatory Exudates," J. Exp. Med., 134: 1131, 1971.

Snyderman, R., Shin, H.S., Phillips, J.K., Gewurz, H., and Mergenhagen, S.E. "A Neutrophil Chemotactic Factor Derived from C5 Upon Interaction of Guinea Pig Serum With Endotoxin," J. Immunol., 103: 413-22, 1969.

Socransky, S.S., Hubersak, C., and Propas, D. "Induction of Periodontal Destruction in Gnotobiotic Rats by a Human Oral Strain of Actinomyces naeslundii," Arch. Oral Biol." 15: 993-95, $197 \overline{0}$.

Socransky, S.S., Macdonald, J.B., Sawyer, and Auskaps, A.M. "Quantitative Studies of the Bacterial Flora of the Periodontium in Rice Rats," Arch. Oral Bio.1., 2: 104-10, 1960 .

Socransky, S.S. and Manganiello, S.D. "The Oral Microbiota of Man From Birth to Senility," I. Periodont., 42: 485-94, 1971 .

stetson, C.A. "Similarities in the Mechanism Determining the Arthus and Shwartzman Phenomena," J. Exp. Med., 94: 347-58, 1951. 
Taichman, N.S., Friedman, H.L., and Uriukara, T. "Inflammation and Tissue Injury I. The Response to Intradermal Injections of Human Dento-Gingival Plaque in Normal and Leucopenic Rabbits," Arch. Oral Biol., 11: 1385-92, 1966.

Tempe1, T.R., Snyderman, R., Jordan, H.V., and Mergenhagen, S.E. "Factors from Saliva and Oral Bacteria Chemotactic for Polymorphonuclear Leukocytes: Their Possible Role in Gingival Inflammation," J. Periodontol., 41: $71-80,1970$.

Thilander, H. "The Effect of Leucocytic Activity on the Structure of the Gingival Epithelium in Man," Acta. Odont. Scand., 21: 431-51, 1963.

Thomason, B.M., Moody, M.D., and Goldman, M. "Staining Bacterial Smears with Fluorescent Antibodies II. Rapid Detection of Varying Numbers of Malleomyces Pseudomallei in Contaminated Materials and Infected Animals," J. Bact., 72: 362-67, 1956.

Walker, W.S., Barlet, R.C., and Kurtz, H.M. "Isolation and Partial Characterization of a Staphylococcal Leucocyte Cytotaxin," J. Bact., 97: 1005-8, 1969.

Ward, P.A. "A Plasmin-Split Fragment of C3 as a New Chemotactic Factor," J. Exp. Med., 126: 189-206, 1967.

Ward, P.A., Lepow, I.H., and Newman, L.J. "Bacterial Factors Chemotactic for Polymorphonuclear Leucocytes," Am. J. Path., 52: 725-36, 1968 .

Ward, P.A. and Newman, I.J. "A Neutrophil Chemotactic Factor from Human C5," J. Immunol., 102: 93-99, 1969.

Wilderman, J.D. "A Cellular study of Plaque," Dent. Progr., 2: 211,1962 .

Williams, B.L., Pantalone, R.M., and Sherris, J.C. "Subgingival Microflora and Periodontitis," J. Periodont. Res.. 11: $1-18$, 1976 . 


\section{APPROVAL SHEET}

The thesis submitted by John A. Ranieri has been read and approved by the following Committee:

Dr. Patrick D. Toto, Director

Professor, Chairman, Departments of General and Oral Pathology, Loyola

Dr. Paul W. Goaz

Professor, Vice Chairman, Oral Diagnosis, Loyola

Dr. Ioannis S. Scarpa

Assistant Professor, Acting Chairman, Biochemistry, Loyola

The final copies have been examined by the director of the thesis and the signature which appears below verifies the fact that any necessary changes have been incorporated and that the thesis is now given final approval by the Committee with reference to content and form.

The thesis is therefore accepted in partial fulfillment of the requirements for the degree of Master of Science.

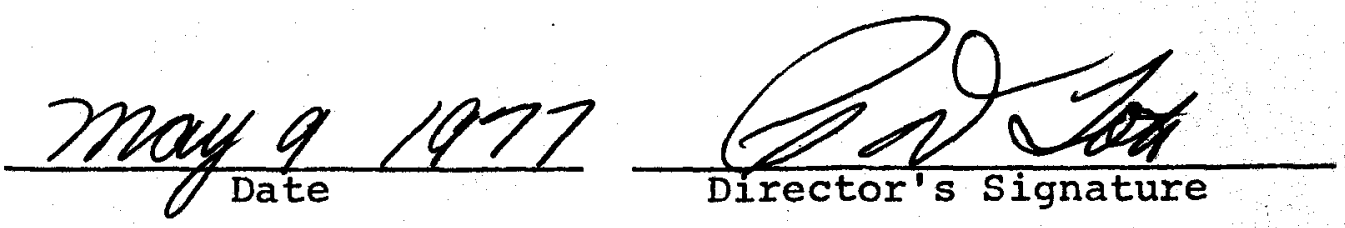

